\title{
An Asian emission inventory of anthropogenic emission sources for the period 1980-2020
}

\author{
T. Ohara ${ }^{1,2}$, H. Akimoto ${ }^{2}$, J. Kurokawa ${ }^{1}$, N. Horii ${ }^{3}$, K. Yamaji ${ }^{2}$, X. Yan ${ }^{4}$, and T. Hayasaka ${ }^{5}$ \\ ${ }^{1}$ National Institute for Environmental Studies, Tsukuba, Ibaraki, Japan \\ ${ }^{2}$ Frontier Research Center for Global Change, Japan Agency for Marine Science and Technology, Yokohama, Japan \\ ${ }^{3}$ Faculty of Economics, Kyushu University, Fukuoka, Japan \\ ${ }^{4}$ State Key Laboratory of Soil and Sustainable Agriculture, Institute of Soil Science, Chinese Academy of Sciences, Nanjing, \\ China \\ ${ }^{5}$ Research Institute for Humanity and Nature, Kyoto, Japan
}

Received: 26 March 2007 - Published in Atmos. Chem. Phys. Discuss.: 22 May 2007

Revised: 15 August 2007 - Accepted: 17 August 2007 - Published: 23 August 2007

\begin{abstract}
We developed a new emission inventory for Asia (Regional Emission inventory in ASia (REAS) Version 1.1) for the period 1980-2020. REAS is the first inventory to integrate historical, present, and future emissions in Asia on the basis of a consistent methodology. We present here emissions in 2000, historical emissions for 1980-2003, and projected emissions for 2010 and 2020 of $\mathrm{SO}_{2}, \mathrm{NO}_{\mathrm{x}}, \mathrm{CO}$, NMVOC, black carbon (BC), and organic carbon (OC) from fuel combustion and industrial sources. Total energy consumption in Asia more than doubled between 1980 and 2003, causing a rapid growth in Asian emissions, by $28 \%$ for BC, $30 \%$ for OC, $64 \%$ for CO, $108 \%$ for NMVOC, $119 \%$ for $\mathrm{SO}_{2}$, and $176 \%$ for $\mathrm{NO}_{\mathrm{x}}$. In particular, Chinese $\mathrm{NO}_{\mathrm{x}}$ emissions showed a marked increase of $280 \%$ over 1980 levels, and growth in emissions since 2000 has been extremely high. These increases in China were mainly caused by increases in coal combustion in the power plants and industrial sectors. NMVOC emissions also rapidly increased because of growth in the use of automobiles, solvents, and paints. By contrast, $\mathrm{BC}, \mathrm{OC}$, and $\mathrm{CO}$ emissions in China showed decreasing trends from 1996 to 2000 because of a reduction in the use of biofuels and coal in the domestic and industry sectors. However, since 2000, Chinese emissions of these species have begun to increase. Thus, the emissions of air pollutants in Asian countries (especially China) showed large temporal variations from 1980-2003. Future emissions in 2010 and 2020 in Asian countries were projected by emission scenarios and from emissions in 2000. For China, we developed three emission scenarios: PSC (policy success case), REF (reference case), and PFC (policy failure case). In the 2020 REF scenario, Asian total emissions of $\mathrm{SO}_{2}, \mathrm{NO}_{\mathrm{x}}$, and
\end{abstract}

Correspondence to: T. Ohara

(tohara@nies.go.jp)
NMVOC were projected to increase substantially by $22 \%$, $44 \%$, and $99 \%$, respectively, over 2000 levels. The 2020 REF scenario showed a modest increase in $\mathrm{CO}(12 \%)$, a lesser increase in $\mathrm{BC}(1 \%)$, and a slight decrease in OC $(-5 \%)$ compared with 2000 levels. However, it should be noted that Asian total emissions are strongly influenced by the emission scenarios for China.

\section{Introduction}

Anthropogenic emissions in Asia are larger than those in Europe and North America today and will continue to increase in the future (Akimoto, 2003). In fact, recent tropospheric satellite observations have demonstrated that $\mathrm{NO}_{\mathrm{x}}$ emissions in China have accelerated impressively since 2000 (Irie et al., 2005; Richter et al., 2005). In light of this situation, the development of Asian emission inventories for the past, present, and future is very important for the understanding and management of the regional and global atmospheric environment.

There are comparatively few Asian inventories of anthropogenic emission sources from East, Southeast, or South Asia. The first Asian inventory was developed by Kato and Akimoto (1992) and Akimoto and Narita (1994); it reported $\mathrm{SO}_{2}$ and $\mathrm{NO}_{\mathrm{x}}$ emissions for 1975, 1980, and 1985-1987. Recently, Streets et al. (2003) developed an emission inventory for use during the ACE-Asia (Asian Pacific Regional Aerosol Characterization Experiment) and TRACE-P (Transport and Chemical Evolution over the Pacific) field campaigns carried out in the East Asia and the Western Pacific region in spring 2001. The campaigns focused on the characterization of gaseous and aerosol species in Asian outflows to the western

Published by Copernicus Publications on behalf of the European Geosciences Union. 
Table 1. Summary of species and emission sources in REAS version 1.1.

\begin{tabular}{|c|c|c|c|c|c|c|c|c|c|c|c|c|}
\hline & Sector & & $\mathrm{SO}_{2}$ & $\mathrm{NO}_{\mathrm{x}}$ & $\mathrm{CO}$ & BC & OC & NMVOC & $\mathrm{CO}_{2}$ & $\mathrm{~N}_{2} \mathrm{O}$ & $\mathrm{NH}_{3}$ & $\mathrm{CH}_{4}$ \\
\hline \multirow{3}{*}{ Anthropogenic } & Combustion & Fossil fuel + biofuel & $\bullet$ & $\bullet$ & $\bullet$ & $\bullet$ & $\bullet$ & $\bullet$ & $\bullet$ & $\bullet$ & $\bullet$ & $\bullet$ \\
\hline & $\begin{array}{c}\text { Non- } \\
\text { combustion }\end{array}$ & $\begin{array}{l}\text { Industrial processes } \\
\text { Oil, solvents etc }\end{array}$ & $\bullet$ & & $\bullet$ & & & - & $\bullet$ & & & \\
\hline & Agriculture & $\begin{array}{c}\text { Agricultural soil } \\
\text { Livestock }\end{array}$ & & • & & & & & & $\bullet$ & $\bullet$ & ๑ \\
\hline & Natural so & & & • & & & & & & $\bullet$ & • & \\
\hline
\end{tabular}

- Data available.

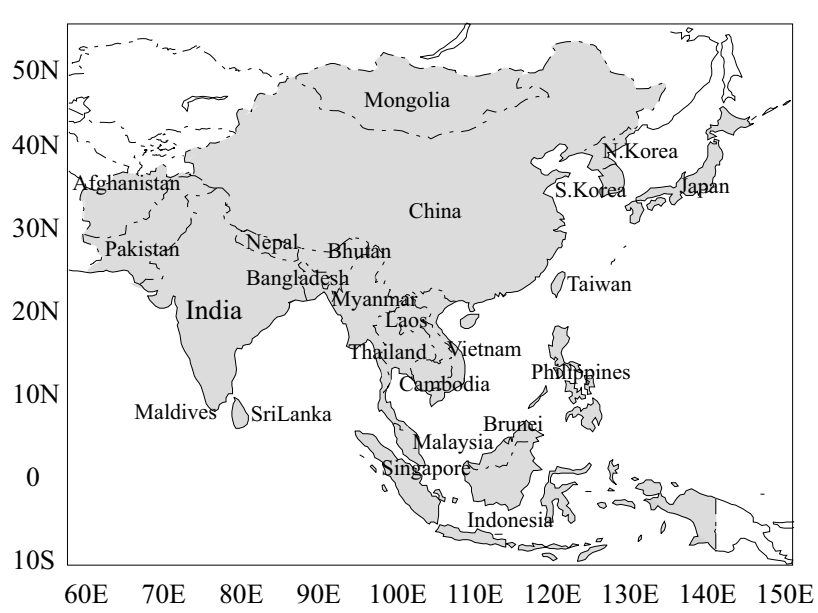

Fig. 1. Inventory domain.

Pacific Ocean, and the inventories included $\mathrm{SO}_{2}, \mathrm{NO}_{\mathrm{x}}, \mathrm{CO}$, nonmethane volatile organic compounds (NMVOC), black carbon (BC), organic carbon (OC), $\mathrm{NH}_{3}$, and $\mathrm{CH}_{4}$. Twentytwo countries and regions in East, Southeast, and South Asia were included, and $1^{\circ} \times 1^{\circ}$ grid maps for the base year (2000) were provided. The Regional Air Pollution Information and Simulation (RAINS-Asia) is a project organized by the International Institute for Applied Systems Analysis (IIASA) and funded by the World Bank for the purpose of constructing a policy tool for the mitigation of acid rain in Asia (Downing et al., 1997). In this study, emission inventories for $\mathrm{SO}_{2}$ with base years of 1990 and 1995, and also projections from 2000 to 2030, were estimated, and the results are available on a CD-ROM (IIASA, 2001). The global emission inventories EDGAR (Emission Database for Global Atmospheric Research; Olivier et al., 1999) and the IIASA inventory (Cofala et al., 2006) naturally include Asian emissions.

Despite the importance of understanding annual variations in past air quality, only a few attempts have been made to estimate the time series of historical Asian emissions. Streets et al. $(2000,2001 \mathrm{a})$ reported trends in country-based emissions of $\mathrm{SO}_{2}$ and $\mathrm{NO}_{\mathrm{x}}$ in Asia during 1985 and 1997; their data were based on the RAINS-Asia emission inventory. Global gridded emissions of $\mathrm{CO}_{2}, \mathrm{CO}, \mathrm{CH}_{4}, \mathrm{NMVOC}, \mathrm{SO}_{2}, \mathrm{NO}_{\mathrm{x}}$, $\mathrm{N}_{2} \mathrm{O}$, and $\mathrm{NH}_{3}$ by sector for the period 1890-1990 have been estimated by Van Aardenne et al. (2001). The emissions data set EDGAR-HYDE was estimated by using historical activity data from the HYDE database (Klein Goldewijk and Battjes, 1997) and historical emission factors based on the uncontrolled emission sources included in EDGAR. However, year-by-year emissions after 1990, which can be expected to show marked variations in Asian countries, were not included.

Future changes in the air quality in Asia will be affected strongly by the expected growth in anthropogenic emissions, which are controlled by economic growth, environmental policy, and future implementation of emissions controls. Projections of Asian emissions have been made by Van Aardenne et al. (1999) for $\mathrm{NO}_{\mathrm{x}}$, Streets and Waldhoff (2000) for $\mathrm{SO}_{2}, \mathrm{NO}_{\mathrm{x}}$, and $\mathrm{CO}$, and Klimont et al. (2001) for $\mathrm{SO}_{2}, \mathrm{NO}_{\mathrm{x}}, \mathrm{NH}_{3}$, and NMVOC. Additionally, Asian emissions have been projected as part of the estimations of global emissions of $\mathrm{SO}_{2}, \mathrm{NO}_{\mathrm{x}}, \mathrm{CO}$, and NMVOC (Cofala et al., 2006) and of carbonaceous particles (Streets et al., 2004).

Thus, it is very important to develop a historical and future emission inventory for multiple species and years covering the whole of Asia. We have developed a new Asian emission inventory (Regional Emission inventory in ASia (REAS), Version 1.1) for the 40 years from 1980 to 2020. REAS is the first inventory to integrate historical, current, and future emissions data for Asia on the basis of a consistent methodology. Table 1 demonstrates the emission sources and chemical species targeted by REAS. The REAS inventory includes $\mathrm{NO}_{\mathrm{x}}, \mathrm{SO}_{2}, \mathrm{CO}, \mathrm{BC}, \mathrm{OC}, \mathrm{CO}_{2}, \mathrm{~N}_{2} \mathrm{O}, \mathrm{NH}_{3}, \mathrm{CH}_{4}$, and NMVOC from anthropogenic activities (combustion, noncombustion, agriculture, and others). The methodology and results for $\mathrm{NO}_{\mathrm{x}}, \mathrm{N}_{2} \mathrm{O}, \mathrm{NH}_{3}$, and $\mathrm{CH}_{4}$ emissions from agricultural sources are explained by Yamaji et al. $(2003,2004)$ and Yan et al. (2003a, b, c). Open biomass burning is not yet included in REAS. 
Here, we focus on the emissions of $\mathrm{NO}_{\mathrm{x}}, \mathrm{SO}_{2}, \mathrm{BC}, \mathrm{OC}$, $\mathrm{CO}$, and NMVOC from fuel combustion and non-combustion sources. Section 2 describes the methodology used in REAS to estimate emissions, including activity data, emission factors, emission scenarios in 2010 and 2020, and grid allocation. Section 3, the results and discussion, covers four topics: (1) Asian and national emissions in 2000; (2) historical emissions between 1980 and 2003; (3) projections of future emissions in 2010 and 2020; and (4) gridded emissions in Asia. Conclusions and a summary are given in Sect. 4.

\section{Methodology}

\subsection{Basic methodology}

The target domain of REAS covers 24 countries in East, Southeast, and South Asia (Fig. 1). Emissions were estimated on the basis of activity data at district levels for China (30 provinces), India (20 states), Japan (6 sub-regions), South Korea (4 sub-regions), and Pakistan (5 sub-regions). For the other countries, national emissions were estimated on the basis of activity data at the national level.

Figure 2 demonstrates the general methodology for the emission estimates in REAS. We estimated the emissions from fuel combustion sources and non-combustion sources as part of anthropogenic activities: transformation (power) sectors (electricity and heat production, oil refineries, manufacture of solid fuels, and other energy and transformation industries); industry sectors (including iron and steel, chemical and petrochemical, non-ferrous metals, and non-metallic minerals); transport sectors (including aviation, roads, railways, and shipping); and other (mainly domestic) sectors (including agriculture, commerce and public, and residential). Emissions of a particular species were estimated as a product of the activity data, emission factors, and removal efficiency of emission controls. Region-specific emission factors for several emission species from subdivided source sectors were developed from a wide range of sources (published or unpublished information) and were used to estimate emissions on district and country levels. These emissions, estimated on district and country levels, were divided into a $0.5^{\circ} \times 0.5^{\circ}$ grid by using index databases, i.e. population data; information on the positions of large point sources (LPSs); land cover data sets; and land area data sets. Here, we give the methodology, data, and data sources of the emission estimations in this inventory. Emissions from fuel combustion sources, including 20 economic sectors and 36 fuel types, were estimated in REAS. Emissions of $\mathrm{SO}_{2}$ and other species (except NMVOC) from stationary sources were estimated by using Eqs. (1) and (2), respectively.

$E=(A / N C V) \times S \times(1-S R) \times(1-R)$

$E: \mathrm{SO}_{2}$ emissions $[\mathrm{kg}]$

$A$ : Energy consumption $[\mathrm{J}]$

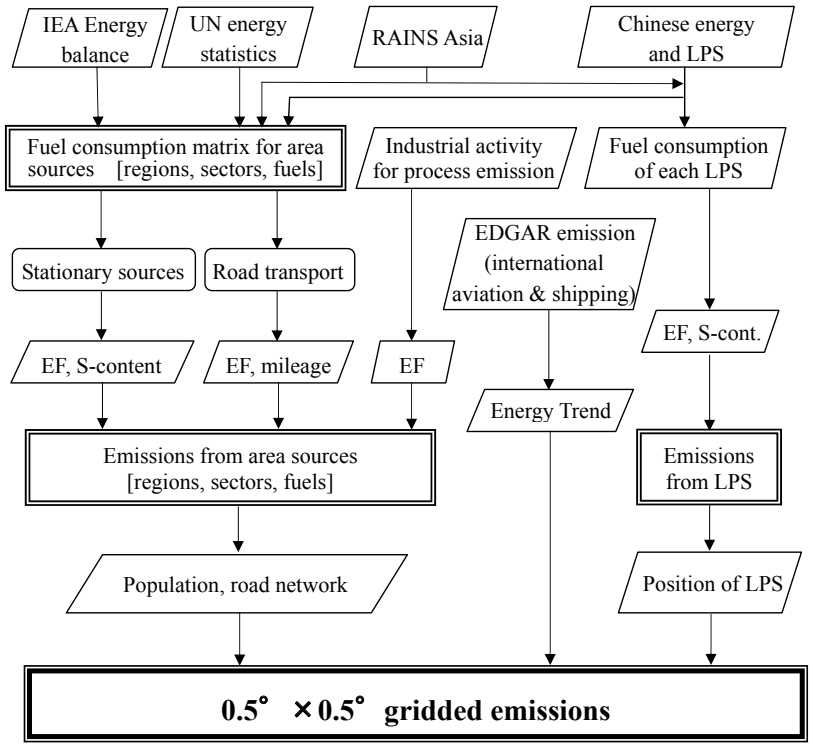

Fig. 2. Flow chart for the estimation of emissions.

$N C V$ : Net calorific value $\left[\mathrm{J} \mathrm{kg}^{-1}\right]$

$S$ : Sulfur content of fuel $\left[\mathrm{kg} \mathrm{kg}^{-1}\right]$

$S R$ : Sulfur retention in ash [-]

$R$ : Removal efficiency [-]

$E=A \times E F \times(1-R)$

$E$ : Emissions $[\mathrm{kg}]$

$A$ : Energy consumption $[\mathrm{J}]$

$E F:$ Emission factor $\left[\mathrm{kg} \mathrm{J}^{-1}\right]$

$R$ : Removal efficiency [-]

For road transport, emissions of $\mathrm{SO}_{2}, \mathrm{NO}_{\mathrm{x}}, \mathrm{CO}, \mathrm{BC}$, and $\mathrm{OC}$ were estimated by the following equation:

$E=A \times E F \times F E /(S G \times N C V)$

$E$ : Emissions $[\mathrm{kg}]$

$A$ : Energy consumption [J]

$E F:$ Emission factor $\left[\mathrm{kg} \mathrm{m}^{-1}\right]$

$F E$ : Fuel economy $\left[\mathrm{m} \mathrm{L}^{-1}\right]$

$S G$ : Specific gravity $\left[\mathrm{kg} \mathrm{L}^{-1}\right]$

$N C V$ : Net calorific value $\left[\mathrm{J} \mathrm{kg}^{-1}\right]$

We classified on-road vehicles into seven types (light-duty gasoline vehicles, heavy-duty gasoline vehicles, light-duty diesel vehicles, heavy-duty diesel vehicles, gasoline buses, diesel buses, and motorcycles). Motor gasoline and diesel oil consumption was distributed to each vehicle type by using traffic volume and fuel economy data, and then the emissions were estimated by using country-specific emission factors by vehicle type. 
Table 2. Fuel consumption by region, sector, and fuel type between 1980 and 2003 (units: PJ).

\begin{tabular}{|c|c|c|c|c|c|c|c|c|c|c|c|c|}
\hline \multirow{2}{*}{ Region } & \multicolumn{3}{|c|}{ Power Plants } & \multicolumn{3}{|c|}{ Industry } & \multicolumn{2}{|c|}{ Transport } & \multicolumn{3}{|c|}{ Domestic } & \multirow{2}{*}{ Total } \\
\hline & Coal & Oil & Others & Coal & Oil & Others & Oil & Others & Coal & Biofuel & Others & \\
\hline 1980 China & 2410 & 963 & 105 & 5498 & 1605 & 875 & 640 & 402 & 3017 & 4751 & 595 & 20860 \\
\hline Japan & 210 & 2525 & 1102 & 525 & 3869 & 1160 & 2108 & 0 & 23 & 122 & 1813 & 13456 \\
\hline Other East Asia & 279 & 514 & 1 & 835 & 992 & 178 & 391 & 0 & 531 & 335 & 288 & 4343 \\
\hline Southeast Asia & 55 & 539 & 14 & 74 & 698 & 345 & 637 & 3 & 22 & 3016 & 459 & 5861 \\
\hline India & 902 & 120 & 18 & 565 & 525 & 906 & 472 & 229 & 323 & 5920 & 284 & 10263 \\
\hline Other South Asia & 0 & 17 & 86 & 40 & 50 & 288 & 138 & 0 & 1 & 1459 & 123 & 2203 \\
\hline Total & 3856 & 4679 & 1325 & 7537 & 7738 & 3752 & 4385 & 634 & 3917 & 15602 & 3563 & 56986 \\
\hline 1985 China & 3547 & 741 & 122 & 6815 & 1652 & 1218 & 823 & 476 & 4138 & 5244 & 619 & 25394 \\
\hline Japan & 569 & 1524 & 1482 & 577 & 3619 & 1065 & 2145 & 0 & 50 & 9 & 1881 & 12921 \\
\hline Other East Asia & 526 & 246 & 39 & 1054 & 1057 & 200 & 483 & 0 & 674 & 356 & 375 & 5011 \\
\hline Southeast Asia & 133 & 502 & 148 & 139 & 755 & 639 & 803 & 3 & 13 & 3244 & 429 & 6807 \\
\hline India & 1529 & 140 & 49 & 851 & 704 & 1078 & 676 & 186 & 411 & 6530 & 374 & 12528 \\
\hline Other South Asia & 1 & 56 & 113 & 51 & 71 & 401 & 194 & 0 & 1 & 1608 & 176 & 2671 \\
\hline Total & 6305 & 3208 & 1954 & 9486 & 7858 & 4601 & 5124 & 666 & 5286 & 16991 & 3854 & 65334 \\
\hline 1990 China & 6046 & 659 & 193 & 8836 & 2518 & 1439 & 1145 & 430 & 4655 & 5788 & 908 & 32618 \\
\hline Japan & 807 & 2035 & 1798 & 626 & 3611 & 1218 & 2823 & 0 & 2 & 9 & 2352 & 15281 \\
\hline Other East Asia & 601 & 421 & 196 & 1042 & 1618 & 262 & 876 & 0 & 536 & 354 & 707 & 6614 \\
\hline Southeast Asia & 312 & 719 & 263 & 179 & 1106 & 1374 & 1263 & 1 & 12 & 3547 & 609 & 9385 \\
\hline India & 2481 & 150 & 145 & 1141 & 865 & 1321 & 996 & 102 & 464 & 7051 & 514 & 15229 \\
\hline Other South Asia & 1 & 100 & 222 & 80 & 87 & 517 & 257 & 0 & 0 & 1782 & 223 & 3269 \\
\hline Total & 10248 & 4086 & 2815 & 11905 & 9804 & 6130 & 7360 & 532 & 5670 & 18532 & 5313 & 82395 \\
\hline 1995 China & 10012 & 714 & 215 & 11313 & 3228 & 1829 & 1813 & 276 & 4099 & 6456 & 1478 & 41433 \\
\hline Japan & 1194 & 1685 & 2061 & 574 & 4137 & 1309 & 3307 & 0 & 1 & 6 & 2653 & 16927 \\
\hline Other East Asia & 990 & 702 & 381 & 868 & 2740 & 390 & 1448 & 0 & 204 & 366 & 1289 & 9377 \\
\hline Southeast Asia & 395 & 879 & 901 & 380 & 1558 & 2095 & 2067 & 1 & 28 & 3579 & 820 & 12701 \\
\hline India & 3929 & 166 & 284 & 1053 & 1219 & 1551 & 1440 & 5 & 486 & 7364 & 667 & 18163 \\
\hline Other South Asia & 7 & 192 & 264 & 83 & 137 & 541 & 371 & 0 & 0 & 1917 & 263 & 3775 \\
\hline Total & 16528 & 4337 & 4106 & 14270 & 13018 & 7715 & 10446 & 283 & 4817 & 19688 & 7170 & 102377 \\
\hline 2000 China & 12679 & 604 & 457 & 10828 & 4447 & 1991 & 2726 & 236 & 3055 & 5289 & 2207 & 44520 \\
\hline Japan & 1702 & 1045 & 2481 & 502 & 4759 & 1398 & 3473 & 0 & 10 & 4 & 2820 & 18194 \\
\hline Other East Asia & 1898 & 544 & 645 & 908 & 3538 & 572 & 1637 & 0 & 167 & 381 & 1313 & 11603 \\
\hline Southeast Asia & 801 & 728 & 1406 & 554 & 1793 & 2559 & 2557 & 1 & 37 & 3787 & 1088 & 15310 \\
\hline India & 5201 & 325 & 422 & 874 & 2382 & 1741 & 1273 & 0 & 355 & 7866 & 948 & 21387 \\
\hline Other South Asia & 4 & 320 & 354 & 84 & 151 & 674 & 469 & 4 & 0 & 2093 & 321 & 4475 \\
\hline Total & 22284 & 3566 & 5766 & 13751 & 17070 & 8936 & 12135 & 241 & 3625 & 19420 & 8697 & 115490 \\
\hline 2003 China & 18584 & 714 & 440 & 13040 & 5436 & 2689 & 3347 & 239 & 3102 & 5401 & 2651 & 55644 \\
\hline Japan & 2132 & 992 & 2596 & 613 & 4806 & 1481 & 3389 & 0 & 10 & 3 & 2757 & 18780 \\
\hline Other East Asia & 2464 & 440 & 983 & 963 & 4236 & 552 & 1798 & 5 & 162 & 329 & 1316 & 13248 \\
\hline Southeast Asia & 1145 & 587 & 1869 & 698 & 2035 & 2824 & 2919 & 5 & 45 & 3978 & 1127 & 17232 \\
\hline India & 5655 & 310 & 567 & 987 & 2470 & 1758 & 1313 & 0 & 388 & 8239 & 1088 & 22776 \\
\hline Other South Asia & 3 & 174 & 556 & 142 & 138 & 778 & 495 & 15 & 0 & 2221 & 356 & 4879 \\
\hline Total & 29984 & 3217 & 7011 & 16443 & 19121 & 10083 & 13262 & 264 & 3707 & 20172 & 9296 & 132559 \\
\hline
\end{tabular}

Additionally, REAS includes $\mathrm{SO}_{2}$ emissions from nonferrous metals and sulfuric acid production and $\mathrm{CO}$ emissions from iron and steel production. These non-combustion emissions were estimated by industrial activity data and process emission factors. NMVOC emissions for 1995 and 2000 were not estimated independently in the present version; they were obtained from Klimont et al. (2002) and Streets et al. (2003).

The emissions from aviation and international shipping in 2000 were estimated from the gridded data for 1995 in EDGAR 3.2 (http://www.mnp.nl/edgar/model/edgarv32/), the rates of change in energy consumption (country value for aviation and Asian total value for international shipping) from 1995 to 2000 in the International Energy Agency (IEA) Energy Balances (2004), and BC and OC emission factors (Cass et al., 1982).

Regional- or country-based emission data, excluding LPSs data, were broken down into grid data with a $0.5^{\circ} \times 0.5^{\circ}$ res- olution by using three kinds of allocation factor: (1) road networks, provided by Streets et al. (2003), for road transport sources; (2) rural populations, provided by Streets et al. (2003), for biofuel combustion in the domestic sector and all fuel combustion in the agricultural sector; and (3) total populations, extracted from the Land Scan Global Population database developed by Oak Ridge National Laboratory (ORNL, 2001), for other area sources. We assumed that the spatial distributions of these allocation factors did not vary in the period 1980-2020. In China, power plants with capacities over $100 \mathrm{MW}$ are treated as LPSs. Information on the locations and fuel consumption of LPSs in China was provided from some institutes related to China State Grid Company. For other countries LPSs information was obtained from RAINS-Asia. In this study, the numbers of LPSs in China and other countries were taken to be 436 and 87, respectively. 


\subsection{Activity data}

Table 2 shows fuel consumption by region, sector, and fuel type between 1980 and 2003. Fuel consumption data from IEA Energy Balances (IEA, 2004) were used for most of the countries, except for the period 1996-2003 in China for reasons described below. For countries whose fuel consumption data were not included in the IEA data, those from RAINSAsia (IIASA, 2001) and the UN Energy Statistics Yearbook (United Nations, 1983-2004) were used. The IEA fuel consumption data for China are distributed to each province by using the China Energy Statistical Yearbook (CESY; National Bureau of Statistics, 1997-2004). For India, the total fuel consumption in the IEA data are subdivided into the fuel consumption for each Indian region by using the RAINSAsia data.

In constructing the REAS, particular concern was paid to the coal consumption trend in China during 1996-2000, which, according to CESY and IEA statistics, was decreasing. These data were verified from GOME satellite observational data for tropospheric $\mathrm{NO}_{2}$ column density in the North China Plain (Akimoto et al., 2006). The $\mathrm{NO}_{2}$ column increase from 1996-2002 averaged for the two reports (Irie et al., 2005; Richter et al., 2005) was about 50\%, whereas the $\mathrm{NO}_{\mathrm{x}}$ emission increases based on the province-by-province data in the China Energy Statistics Yearbook (PBP-CESY) and the IEA data were $25 \%$ and $15 \%$, respectively. The country-total data from CESY were even lower than the PBPCESY and IEA data. The discrepancy in increasing trends between the satellite data and the PBP-CESY emission inventory could be within the uncertainty level, with the reservation that the increase in total fuel consumption in PBPCESY may still be underestimated, particularly since 1999 . After performing these verifications we adopted the fossil fuel consumption data of PBP-CESY for 1996-2003. Recently, statistical data on coal consumption were modified to higher values in the China Statistical Yearbook (National Bureau of Statistics, 2006), and this fact may support our conclusion.

Biofuel consumption was obtained from other data sources. For China, the provincial consumption of biofuel for 1995 or 2000 was obtained from Yan et al. (2006) and RAINS-Asia. For other countries, regional consumption data for 1990 or 1995 in RAINS-Asia were used. Data for the period 1980-2000 were extrapolated from these data of regional biofuel consumption for 1990 or 1995 or 2000 by using international statistics for fuelwood (FAO, 2000) and primary solid biomass (IEA, 2004). For non-combustion sources, an industrial activity data set (production of nonferrous metals, sulfuric acid, iron, and steel) was derived from international statistics (e.g., USGS Minerals Yearbook, 2006; UN Statistics Yearbook, 1983-2004).

\subsection{Emission factors}

Emission factors were determined for each of the sectors, fuels, and countries for 1995 and 2000. Table 3 shows the mean emission factors for fuel combustion in 2000. Emission factors by economic sector, fuel type, combustion facility, country, and region were compiled from a wide range of literature, such as Kato et al. (1991), Kato and Akimoto (1992), AP-42 (US EPA, 1999), the IPCC Guideline (1997), the EMEP/CORINAIR Emission Inventory Guidebook (EEA, 2000), and Streets et al. (2003). Emission factors for other years in the period 1980-2003 were then estimated by using the emission control levels in each country. Because the historical data for emission factors were unavailable, it was assumed that the emission factors (except for those from some stationary sources in some developed countries and from the automobile sources in many countries) did not vary throughout the period. For Japan, the time variations of countryspecific emissions factors in the period 1980-2003 were determined from a large number of domestic research reports (e.g. Kannari et al., 2007).

The sulfur contents of coal for power plants and industry and those of some types of oil (motor gasoline, kerosene, heavy fuel oil, and diesel oil) in China for pre-1980, 1990, 1995, and 2000 were determined from the information of Kato et al. (1991), Streets et al. (2000), and the China Coal Industry Yearbook 2002 (State Administration for Coal Safety, 2003). Because $\mathrm{SO}_{2}$ emissions in China depended strongly on the sulfur content of coal, province-by-province data for power plants and other sectors were used in this estimation. The average sulfur content of coal in China was $1.35 \%$ pre-1985, $1.27 \%$ in $1990,1.12 \%$ in 1995 , and $1.08 \%$ in 2000. A simple interpolation was used to generate values for each year during the period 1985-2000. For India, we prepared state-by-state data on the sulfur content of coal on the basis of the data reported by Reddy et al. (2001a). For other countries, the RAINS-Asia and Kato et al. (1991) databases on sulfur content in fuel were used. On the basis of Streets et al. (2000) and others, adjustments were made to account for the reduction in sulfur content by national regulation in Japan, Taiwan, South Korea, Hong Kong, Singapore, and Thailand during the period 1990-2000. It was assumed that sulfur retention values in ash were $5 \%$ to $30 \%$ (depending on country, sector, and coal type) for coal and $0 \%$ for other fuels.

$\mathrm{SO}_{2}$ emission factors for oil (excluding motor gasoline, kerosene, heavy fuel oil, and diesel oil), and gas were provided mainly from Kato et al. (1991), AP-42, the IPCC Guideline, and the EMEP/CORINAIR Guidebook and were provided from Garg et al. (2001) for biofuel. After 1990, the efficiencies of removal of $\mathrm{SO}_{2}$ by desulfurization were defined for power plants, industry, and oil refineries on the basis of Wang et al. (2000) in the case of China and RAINS-Asia for other countries. Because post-2000 data were unavailable, it was assumed that these parameters remained constant 
Table 3. Mean emission factors for fuel combustion in 2000.

\begin{tabular}{|c|c|c|c|c|c|c|c|c|c|c|c|c|c|}
\hline & \multirow{2}{*}{ Region } & \multicolumn{3}{|c|}{ Power Plants } & \multicolumn{3}{|c|}{ Industry } & \multicolumn{2}{|c|}{ Transport } & \multicolumn{3}{|c|}{ Domestic } & \multirow{2}{*}{ Total } \\
\hline & & Coa1 & $0 i 1$ & 0thers & Coal & $0 i 1$ & Others & $0 i 1$ & 0thers & Coal & Biofue1 & 0thers & \\
\hline \multirow{3}{*}{$\begin{array}{l}\mathrm{SO}_{2} \\
(\mathrm{~g} / \mathrm{GJ})\end{array}$} & China & 833.6 & 590.5 & 73.4 & 934.2 & 148.7 & 217.1 & 80.5 & 711.3 & 760.3 & 51.4 & 93.2 & 569.5 \\
\hline & Japan & 26.2 & 61.1 & 17.4 & 250.1 & 35.9 & 71.8 & 20.0 & - & 317.2 & 0.0 & 30.1 & 38.8 \\
\hline & Other & 504.2 & 674.4 & 8.6 & 536.5 & 310.3 & 41.8 & 145.1 & 0.0 & 376.4 & 47.9 & 124.2 & 152.4 \\
\hline \multirow{3}{*}{$\begin{array}{l}\text { NOx } \\
(\mathrm{g} / \mathrm{GJ})\end{array}$} & China & 298.8 & 279.2 & 161.2 & 241.8 & 79.8 & 78.6 & 1017. 1 & 241.2 & 95.0 & 82.9 & 110.8 & 246.3 \\
\hline & Japan & 66.8 & 88.8 & 42.9 & 201.6 & 43.5 & 40.4 & 267.4 & - & 250.3 & 0.0 & 87.4 & 102.0 \\
\hline & Other & 267.0 & 303.1 & 189.8 & 240.7 & 81.2 & 79.7 & 921.1 & 79.7 & 122.9 & 81.4 & 74.1 & 157.3 \\
\hline \multirow{3}{*}{$\begin{array}{l}\mathrm{C} 0 \\
(\mathrm{~g} / \mathrm{GJ})\end{array}$} & China & 143.8 & 59.4 & 967.0 & 4366.4 & 54.3 & 23.4 & 6970.1 & 143.3 & 5706.1 & 7636.7 & 220.2 & 3196.9 \\
\hline & Japan & 61.2 & 32.8 & 28.0 & 163.8 & 25.5 & 21.9 & 498.5 & - & 176.1 & 0.0 & 124.0 & 134. 4 \\
\hline & Other & 154.3 & 83.0 & 319.1 & 3934. 3 & 44.3 & 2296.7 & 3612.1 & 12.7 & 5851.6 & 7467.2 & 102.7 & 2157.1 \\
\hline \multirow{3}{*}{$\begin{array}{l}\mathrm{BC} \\
(\mathrm{g} / \mathrm{GJ})\end{array}$} & China & 1.0 & 8.1 & 1.0 & 7.5 & 3.1 & 0.0 & 13.4 & 5.0 & 152.4 & 88.0 & 3.6 & 24.5 \\
\hline & Japan & 0.1 & 8.4 & 0.1 & 0.7 & 1.7 & 0.0 & 13.9 & - & 152.4 & 0.0 & 2.6 & 4. 1 \\
\hline & Other & 1.2 & 8.1 & 0.4 & 4.8 & 3.2 & 3.2 & 29.2 & 0.0 & 147.0 & 83.8 & 2.4 & 20.3 \\
\hline \multirow{3}{*}{$\begin{array}{l}\text { OC } \\
(\mathrm{g} / \mathrm{GJ})\end{array}$} & China & 0.2 & 6.1 & 0.5 & 1.6 & 2.3 & 0.0 & 11.6 & 0.9 & 123.3 & 399.1 & 4. 1 & 57.6 \\
\hline & Japan & 0.0 & 6.2 & 0.4 & 0.2 & 1.2 & 0.0 & 4.9 & - & 123.6 & 0.0 & 4.5 & 2.4 \\
\hline & 0ther & 0.3 & 6.1 & 0.3 & 1.2 & 2.4 & 15.7 & 24.0 & 0.0 & 119.3 & 418.6 & 4.8 & 83.2 \\
\hline
\end{tabular}

after 2000 .

$\mathrm{NO}_{\mathrm{x}}$ emission factors, excluding those from automobile sources, were derived from Kato et al. (1991), AP-42, the IPCC Guideline, and the EMEP/CORINAIR Guidebook. Additionally, Streets et al. (1998), and Zhang et al. (2000) were used. Because $\mathrm{NO}_{\mathrm{x}}$ emissions in the developed countries of Asia depended on emission controls after the 1980s, these effects were reflected in the emission factors and removal efficiencies for Japan, Taiwan, South Korea, Hong Kong, and Singapore (where national regulations are applied to major stationary sources, especially in the case of power plants and industry sectors), based on information in RAINSAsia. For other countries, uncontrolled emission factors were used throughout the period 1980-2003.

Excluding emissions from automobile sources, the $\mathrm{BC}$ and OC emission factors for 1995 and 2000 were provided by Streets et al. (2001b, 2003). These emission factors were classified into those for developed countries (Japan, South Korea, Taiwan, Hong Kong, and Singapore) and other countries known to have no emission controls. For the other countries it was assumed that the emission factors, which were considered to be uncontrolled, did not vary throughout the period 1980-2003. On the other hand, the emission factors for developed countries were changed in the period 1980 2003: (1) before 1985, emission factors were uncontrolled; (2) between 1985 and 1995 emission factors were interpolated from the 1985 and 1995 values; (3) between 1995 and 2000 emission factors were interpolated from the 1995 and 2000 values; and (4) after 2000 emission factors for 2000 were used.

$\mathrm{CO}$ emission factors, excluding those from automobile sources, were derived from Kato et al. (1991), AP-42, the IPCC Guideline, and the EMEP/CORINAIR Guidebook. Additionally, Veldt and Berdowski (1995), Zhang et al. (2000), and Streets et al. (2003) were used for biofuel emissions. Recently, Streets et al. (2006) updated the a priori Chinese CO emission inventory (Streets et al., 2003) by making some improvements in the emission factors for industrial sectors. These estimates for Chinese CO emissions in 2001 were $31 \%$ higher than the former estimates for 2000 (Streets et al., 2003) and agreed with some of the results obtained by inverse and forward modeling. This increase was caused mainly by some improvements in the emission factors from coal combustion. Therefore, we based our emission factors for coal combustion in power plants, by industry, and by the residential sector on the data of Streets et al. (2006). However, for residential coal combustion we selected an emission factor $(150 \mathrm{~kg} / \mathrm{t})$, which was the close to the average of the value for hand-feed stokers $(124 \mathrm{~kg} / \mathrm{t})$ by Streets et al. (2006) and the maximum value for coal stoves $(170 \mathrm{~kg} / \mathrm{t})$ by Zhang et al. (1999). These are comparatively rough assumptions and need to be improved in future. These emission factors were considered invariant throughout the period 1980-2003 in all developing countries.

Automobile emissions in the period 1980-2003 were calculated by using country-specific emission factors under country-specific emission controls. For Japan, year-by-year emissions factors for the period 1980-2003 were developed from a large number of domestic research reports. For other countries the emission factors were determined by the following method. We were able to collect the $\mathrm{NO}_{\mathrm{x}}$ emission factors for around 1995 in several modeled countries (China, South Korea, Taiwan, Thailand, Philippines, Indonesia, and India). Other countries were assigned the emission factors of those modeled countries that they resembled. For CO, BC, and $\mathrm{OC}$ the emission factors for 2000 were obtained from Streets et al. (2003). These emission factors were used as the values for the base year of 1995 or 2000 . For other years we 
calculated the emissions by using the emission factor for the base year and country-specific information (Minato, 2002; Nissan Automobile Corporation, 2005) on emission controls and car age profiles.

Process emission factors were gathered from Kato et al. (1991) and Kato and Akimoto (1992) for $\mathrm{SO}_{2}$ emissions and from Streets et al. (2003) for CO emissions. They were invariable throughout the period 1980-2003. Finally, NMVOC emissions for the period 1980-2003 were calculated by an extrapolation of NMVOC emissions for 1995 and 2000 by using an appropriate indicator per sector. Emissions from fuel combustion sources were scaled in time by using fuel consumption data. National production or fuel (gas and oil) consumption was used to scale non-combustion emissions related to fuel use. For other sectors the Gross Domestic Product (GDP) was used as a scaling factor (provinces of China: China Statistical Yearbook; other countries: World Bank, 2006).

\subsection{Projection of future emissions}

Future projection of Asian emissions was performed on the basis of emission scenarios and emissions for 2000. Three emission scenarios for China have been developed for the years 2010 and 2020 by Zhou et al. (2003). The socioeconomic indices, such as population, urbanization, and GDP, are almost the same under these scenarios. The population in 2020 (1.45-1.49 billion) is about equal to that of the IPCC B2 scenario (1.45 billion) (Nakicenovic and Swart, 2000). The GDP growth rate from 2000 to $2020\left(7.3 \% \mathrm{y}^{-1}\right.$ before 2010 and $6.7 \% \mathrm{y}^{-1}$ after 2010) is close to that of the A2 scenario of IPCC $\left(7 \% \mathrm{y}^{-1}\right)$ (Nakicenovic and Swart, 2000).

The first scenario was termed the Policy Failed Case scenario, or PFC. This is a pessimistic scenario with high emission rates caused by continuation of the current energy structure, increased energy consumption, and the slow deployment of new energy technologies and new emission control technologies. The second scenario was termed the Reference scenario, or REF. This was a sustainable scenario with moderate emission rates caused by the suppression of energy consumption through energy conservation, a change to clean energy, and the moderate deployment of new energy technologies and new emission control technologies. We considered that this represented our "best guess" as to what emissions in Asia will be in 2010 and 2020. The third scenario was termed the Policy Succeed Case scenario, or PSC. This was the optimistic case, with low emission rates owing to the implementation of strong energy and environmental policies and the fast deployment of new energy technologies and new emission control technologies. Each concept - PSC, REF, and $\mathrm{PFC}$ - resembled that of the $\mathrm{B} 1$ scenario, the $\mathrm{B} 2$ scenario, and the A2 scenario of IPCC (Nakicenovic and Swart, 2000), respectively.

In the research project of the China Energy Research Institute and National Lawrence Berkley Laboratory (Zhou

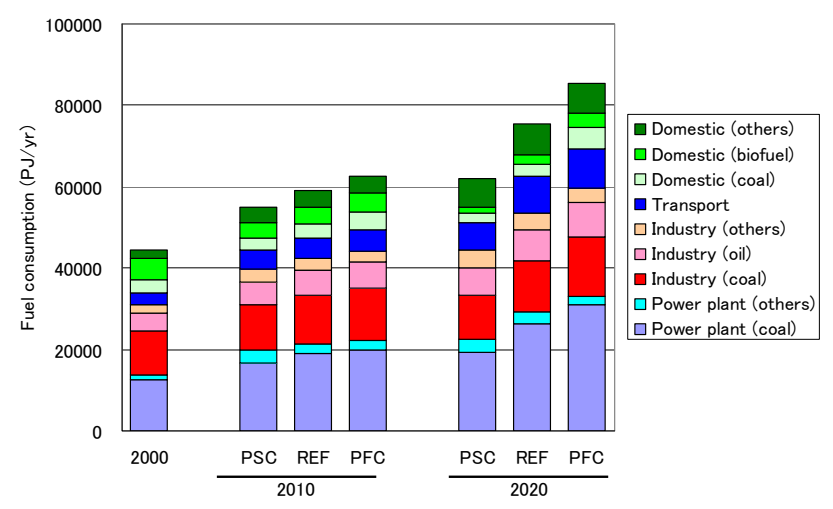

Fig. 3. Chinese fuel consumption in 2000, 2010, and 2020 under the three REAS scenarios.

et al., 2003), fuel consumptions under the PSC, REF, and PFC scenarios were provided from forecasts by a simulation model, the Long-range Energy Alternatives Planning system (LEAP; available at http://forum.seib.org/leap), developed by the Stockholm Environment Institute. Chinese fuel consumption for the years 2010 and 2020 are presented in Fig. 3. Total fuel consumption in China in 2010 was 1.22 (PSC), 1.30 (REF), and 1.35 (PFC) times that in 2000. There is expected to be a further marked increase by 2020. There should be increases in fuel consumption of $39 \%$ (PSC), $63 \%$ (REF), and 77\% (PFC), between 2000 and 2020. In particular, the differences in coal consumption by power plants between the three scenarios are important to note. For other countries, fuel consumption in 2010 and 2020 was calculated on the basis of Reference Scenario Projections in the "World Energy Outlook" (IEA, 2002).

Changes in emission factors were considered only in terms of the following: (1) the efficiencies of removal of $\mathrm{SO}_{2}$ by the power plants and industry sector under the three scenarios in China (Wang et al., 2002). For other countries, removal efficiencies by power plants were set on the basis of RAINSAsia and on the assumption that these would be $99 \%$ in 2030; (2) the emission factors of $\mathrm{NO}_{\mathrm{x}}$ for power plants under the three scenarios in China. It was assumed that those in 2020 would be the same as the Japanese values for the year 2000 under the PSC scenario, as the Chinese 2000 values under the PFC scenario, and as the average values of those for PSC and PFC scenarios under the REF scenario. For other countries, efficiencies of removal by power plants were set on the assumption that the 2030 values would reach the new technology level in RAINS-Asia; and (3) for the road transport sector, country-specific information on emission controls (Nissan Automobile Corporation, 2005).

Non-combustion emissions in 2010 and 2020 were estimated by using 2000 emissions and the increment rate of GDP under each scenario, except in the case where data on the industrial production of iron, cement, and some metals were available for the three scenarios in China. NMVOC 
Table 4. Summary of national emissions in $2000^{\mathrm{a}}$.

\begin{tabular}{|c|c|c|c|c|c|c|}
\hline Country & $\mathrm{SO}_{2}$ & $\mathrm{NO}_{\mathrm{x}}$ & $\mathrm{BC}$ & $\mathrm{OC}$ & $\mathrm{CO}$ & NMVOC \\
\hline China & 27555 & 11186 & 1093 & 2563 & 137011 & 14730 \\
\hline Japan & 926 & 1959 & 75 & 44 & 2661 & 1880 \\
\hline S. Korea & 986 & 1559 & 33 & 57 & 4627 & 1134 \\
\hline N. Korea & 297 & 221 & 42 & 117 & 5363 & 200 \\
\hline Mongolia & 88 & 41 & 4 & 13 & 395 & 23 \\
\hline Taiwan & 266 & 648 & 10 & 10 & 2299 & 502 \\
\hline Macau & 4 & 5 & 0 & 0 & 24 & - \\
\hline Brunei & 3 & 20 & 0 & 1 & 43 & 43 \\
\hline Cambodia & 30 & 48 & 9 & 45 & 802 & 113 \\
\hline Indonesia & 1073 & 1653 & 189 & 889 & 20890 & 5310 \\
\hline Laos & 9 & 18 & 3 & 16 & 372 & 61 \\
\hline Malaysia & 219 & 388 & 13 & 30 & 2878 & 986 \\
\hline Myanmar & 83 & 93 & 35 & 178 & 3413 & 517 \\
\hline Philippines & 712 & 473 & 23 & 78 & 5500 & 969 \\
\hline Singapore & 287 & 157 & 15 & 61 & 1045 & 81 \\
\hline Thailand & 998 & 591 & 34 & 98 & 10892 & 2124 \\
\hline Vietnam & 235 & 330 & 92 & 437 & 8679 & 886 \\
\hline Bangladesh & 106 & 169 & 67 & 266 & 5410 & 483 \\
\hline Bhutan & 5 & 8 & 2 & 9 & 205 & 21 \\
\hline India & 6140 & 4730 & 795 & 3268 & 79382 & 8638 \\
\hline Nepal & 26 & 41 & 27 & 136 & 2404 & 206 \\
\hline Pakistan & 1095 & 640 & 112 & 445 & 9016 & 1135 \\
\hline Sri Lanka & 97 & 120 & 17 & 61 & 1557 & 196 \\
\hline Afghanistan & 7 & 12 & 9 & 50 & 547 & - \\
\hline Maldives & 1 & 2 & 0 & 0 & 6 & - \\
\hline Aviation $^{\mathrm{b}}$ & 6 & 199 & 3 & 1 & 92 & - \\
\hline Shipping ${ }^{\mathrm{c}}$ & 1525 & 2005 & 26 & 10 & 21 & - \\
\hline All Asia & 42778 & 27316 & 2728 & 8883 & 305533 & 40238 \\
\hline
\end{tabular}

a Data are in $\mathrm{kty}^{-1}$.

${ }^{\mathrm{b}}$ Fossil fuel use for international aviation.

c Fossil fuel use for international shipping.

emissions were estimated by extrapolation of NMVOC emissions for 2000 by using national or regional values of fuel consumption for fuel combustion and non-combustion sources related to fuel use, and of GDP for other emission sources.

\section{Results and discussion}

\subsection{Asian and national emissions in 2000}

Table 4 summarizes national emissions in 2000 and Table 5 shows regional emissions in 2000 by emitting sector and fuel type.

\subsection{1 $\quad \mathrm{SO}_{2}$}

Total Asian emissions of $\mathrm{SO}_{2}$ was 42.8 Mt in 2000; China at $27.6 \mathrm{Mt}(65 \%)$ and India at $6.1 \mathrm{Mt}(14 \%)$ were the highemission countries. In terms of sectoral and fuel-type contribution, emissions from coal combustion were dominant
(70\%); in particular, those from power plants and industry were major sources with $35 \%$ and $28 \%$, respectively, of total emissions. In China, the country with the highest emission rates, the contribution of coal combustion to total emissions was as high as $84 \%$. In India, the country with the second-highest emission rate, emissions from coal-burning power plants accounted for around half (47\%), whereas the contribution of emissions from coal combustion to the total emissions (58\%) was smaller than that of China (84\%).

Table 6 shows the emissions for 2000 from different inventories, excluding emissions from international aviation and shipping and from open biomass burning. We compared the values in the Asian inventories REAS and TRACE-P (Streets et al., 2003) and the global inventories IIASA (http://www.iiasa.ac.at/rains/global_emiss/ global_emiss1.html) and EDGAR 32FT2000 (http://www. mnp.nl/edgar/model/v32ft2000edgar/). For Asian emission of $\mathrm{SO}_{2}$, the REAS value (41.2 Mt) was the same as the IIASA one $(41.2 \mathrm{Mt})$, whereas the TRACE-P value $(32.9 \mathrm{Mt})$ was 
Table 5. Regional emissions in 2000 by emitting sector and fuel type ${ }^{\mathrm{a}}$.

\begin{tabular}{|c|c|c|c|c|c|c|c|c|c|c|c|c|c|c|c|}
\hline & \multicolumn{3}{|c|}{ Power Plants } & \multicolumn{4}{|c|}{ Industry } & \multicolumn{2}{|c|}{ Transport } & \multicolumn{3}{|c|}{ Domestic } & \multirow[t]{2}{*}{ Aviation $^{\mathrm{b}}$} & \multirow[t]{2}{*}{ Shipping $^{c}$} & \multirow[t]{2}{*}{ Total } \\
\hline & Coal & Oil & Others & Coal & Oil & Others & Process & Oil & Others & Coal & Biofuel & Others & & & \\
\hline \multicolumn{16}{|c|}{ China } \\
\hline $\mathrm{SO}_{2}$ & 10569 & 357 & 34 & 10464 & 719 & 432 & 1794 & 219 & 168 & 2323 & 272 & 206 & & & 27555 \\
\hline $\mathrm{NO}_{\mathrm{x}}$ & 3788 & 169 & 74 & 2839 & 357 & 156 & & 2773 & 57 & 290 & 439 & 245 & & & 11186 \\
\hline $\mathrm{BC}$ & 13 & 5 & 0 & 85 & 14 & 0 & & 37 & 1 & 465 & 465 & 8 & & & 1093 \\
\hline OC & 3 & 4 & 0 & 17 & 10 & 0 & & 32 & 0 & 377 & 2111 & 9 & & & 2563 \\
\hline $\mathrm{CO}$ & 1824 & 36 & 442 & 47633 & 241 & 47 & 9442 & 19003 & 34 & 17431 & 40391 & 486 & & & 137010 \\
\hline \multicolumn{16}{|c|}{ India } \\
\hline $\mathrm{SO}_{2}$ & 2865 & 216 & 3 & 490 & 1339 & 63 & 241 & 199 & 0 & 165 & 348 & 212 & & & 6140 \\
\hline $\mathrm{NO}_{\mathrm{x}}$ & 1543 & 185 & 81 & 249 & 228 & 161 & 0 & 1564 & 0 & 45 & 618 & 56 & & & 4730 \\
\hline $\mathrm{BC}$ & 8 & 2 & 0 & 7 & 8 & 11 & 0 & 78 & 0 & 62 & 616 & 2 & & & 795 \\
\hline OC & 2 & 2 & 0 & 1 & 6 & 56 & 0 & 62 & 0 & 50 & 3083 & 6 & & & 3268 \\
\hline $\mathrm{CO}$ & 936 & 71 & 262 & 4088 & 160 & 6978 & 1461 & 7093 & 0 & 2253 & 56058 & 22 & & & 79382 \\
\hline \multicolumn{16}{|c|}{ All Asia } \\
\hline $\mathrm{SO}_{2}$ & 14598 & 1713 & 101 & 12102 & 3750 & 803 & 2631 & 1150 & 168 & 2536 & 948 & 747 & 6 & 1525 & 42778 \\
\hline $\mathrm{NO}_{\mathrm{x}}$ & 6012 & 842 & 717 & 3695 & 1217 & 690 & & 9169 & 57 & 361 & 1588 & 763 & 199 & 2005 & 27316 \\
\hline $\mathrm{BC}$ & 22 & 29 & 2 & 99 & 48 & 18 & & 258 & 1 & 549 & 1649 & 24 & 3 & 26 & 2728 \\
\hline OC & 6 & 22 & 2 & 21 & 35 & 87 & & 191 & 0 & 445 & 8025 & 39 & 1 & 10 & 8883 \\
\hline $\mathrm{CO}$ & 3147 & 229 & 1414 & 57478 & 713 & 18747 & 13680 & 42176 & 34 & 20710 & 145879 & 1213 & 92 & 21 & 305533 \\
\hline
\end{tabular}

a Data are in $\mathrm{kty}^{-1}$.

$\mathrm{b}$ Fossil fuel use for international aviation.

${ }^{\mathrm{c}}$ Fossil fuel use for international shipping.

$20 \%$ lower and that of EDGAR (56.0 Mt) was 36\% higher than that of REAS. The distributions of emissions among sectors in REAS and IIASA were similar (data not shown).

Table 7 compares the Chinese emissions from 1995 to 2003 according to REAS and other inventories, including the values estimated by the State Environmental Protection Administration, China (SEPA, 2003). For $\mathrm{SO}_{2}$ emissions in 2000, the REAS value (27.6 Mt) was almost the same as the IIASA one (27.7 Mt) but higher than those of SEPA (20.0 Mt) and TRACE-P (20.3 Mt). The main reason is the differences in fuel consumption values used in each inventory: total fuel consumption used in TRACE-P (Streets et al., 2003) was $36201 \mathrm{PJ}$ (coal consumption $18189 \mathrm{PJ}$ ), whereas that used in REAS was $44520 \mathrm{PJ}$ (coal consumption $26797 \mathrm{PJ}$ ) - 1.23 times the total fuel consumption and 1.47 times the coal in TRACE-P. These differences reflect the fact that coal consumption for 2000 in PBP-CESY, which was used in REAS, was 1.5 times that in CESY (Akimoto et al., 2006). On the other hand, EDGAR estimated emissions in China in 2000 to be $34.2 \mathrm{Mt}$ - much higher than the values used in other inventories.

Table 8 compares the Indian emissions for 1995 and 2000 as estimated by REAS and other inventories. For $\mathrm{SO}_{2}$ emissions in 2000 in India, REAS estimated $6.1 \mathrm{Mt}$, which is very close to the value reported by IIASA $(5.9 \mathrm{Mt})$. However the TRACE-P value (5.5 Mt) was slightly lower and that of EDGAR (7.8 Mt) much higher than the REAS and IIASA values; these results are similar to those for the Chinese emissions.
It should be noted that the $\mathrm{SO}_{2}$ emissions in EDGAR were larger than those in other emission inventories, with the exception of emissions from other South Asia (Table 6). For example, EDGAR estimated emissions from China in 2000 as $34.2 \mathrm{Mt}$, compared with about $20-28 \mathrm{Mt}$ in other inventories. Because EDGAR was the inventory most widely used for global modeling, the marked discrepancy in Asia needs to be resolved (Akimoto and Ohara, 2004).

\subsection{2 $\mathrm{NO}_{\mathrm{x}}$}

Total emissions of $\mathrm{NO}_{\mathrm{x}}$ in Asia were $27.3 \mathrm{Mt}$ in 2000 (Table 4); China at $11.2 \mathrm{Mt}(65 \%)$ and India at $4.7 \mathrm{Mt}(17 \%)$ were high-emission countries, as was the case for $\mathrm{SO}_{2}$ emissions. Japan (7\%), South Korea (6\%), and Indonesia (6\%) also made relatively large contributions. In terms of sectoral and fuel-type contributions (Table 5), transport oil use was the largest (34\%), followed by coal use in power plants (22\%) and industrial coal use (14\%). For contributions by fuel type alone, oil use (41\%) was slightly greater than coal use (37\%), unlike the case with $\mathrm{SO}_{2}$ emissions, where coal use was the dominant contributor. In China, the country with the largest emissions, coal-burning power plants were the largest emitters (34\%), followed by industrial coal use and transport oil use (both at 25\%). In India, the contributions of coal-burning power plants and transport oil use were dominant (both at 33\%). Additionally, domestic biofuel use was a large contributor (13\%) - larger than in China (4\%).

Comparison of the Asian total emissions for 2000 (Table 6), as estimated by REAS and other inventories revealed that the REAS value $(25.1 \mathrm{Mt})$ was almost the same as the 
Table 6. Comparison of estimates of Asian emissions in $2000^{\mathrm{a}}$.

\begin{tabular}{|c|c|c|c|c|}
\hline Inventory projects & REAS & TRACE-P ${ }^{\mathrm{b}}$ & EDGAR $3.2^{\mathrm{C}}$ & IIASA $^{\mathrm{d}}$ \\
\hline \multicolumn{5}{|c|}{$\mathrm{SO}_{2}$} \\
\hline China & 27555 & 20303 & 34197 & 27711 \\
\hline Japan & 926 & 800 & 2210 & 871 \\
\hline Other East Asia & 1642 & 1513 & 6511 & 1581 \\
\hline Southeast Asia & 3649 & 3150 & 4127 & 3411 \\
\hline India & 6140 & 5462 & 7846 & 5919 \\
\hline Other South Asia & 1336 & 1634 & 1130 & 1658 \\
\hline All Asia & 41248 & 32862 & 56021 & 41152 \\
\hline \multicolumn{5}{|c|}{$\mathrm{NO}_{\mathrm{x}}$} \\
\hline China & 11186 & 10531 & 13728 & 11722 \\
\hline Japan & 1959 & 2188 & 2725 & 2504 \\
\hline Other East Asia & 2473 & 2137 & 3006 & 2260 \\
\hline Southeast Asia & 3770 & 3058 & 3913 & 3944 \\
\hline India & 4730 & 4047 & 6285 & 4563 \\
\hline Other South Asia & 992 & 713 & 1444 & 800 \\
\hline All Asia & 25112 & 22674 & 31102 & 25792 \\
\hline \multicolumn{5}{|c|}{$\mathrm{BC}$} \\
\hline China & 1093 & 936 & & \\
\hline Japan & 75 & 52 & & \\
\hline Other East Asia & 89 & 52 & & \\
\hline Southeast Asia & 413 & 321 & & \\
\hline India & 795 & 517 & & \\
\hline Other South Asia & 234 & 142 & & \\
\hline All Asia & 2699 & 2020 & & \\
\hline \multicolumn{5}{|c|}{ OC } \\
\hline China & 2563 & 2657 & & \\
\hline Japan & 44 & 62 & & \\
\hline Other East Asia & 197 & 133 & & \\
\hline Southeast Asia & 1833 & 1370 & & \\
\hline India & 3268 & 2190 & & \\
\hline Other South Asia & 967 & 626 & & \\
\hline All Asia & 8872 & 7038 & & \\
\hline \multicolumn{5}{|c|}{$\mathrm{CO}$} \\
\hline China & 137011 & 141700 & 86518 & 75442 \\
\hline Japan & 2661 & 6576 & 10718 & 5324 \\
\hline Other East Asia & 12708 & 8454 & 10789 & 6002 \\
\hline Southeast Asia & 54514 & 34045 & 42616 & 39800 \\
\hline India & 79382 & 51081 & 58631 & 46753 \\
\hline Other South Asia & 19145 & 11165 & 22231 & 12232 \\
\hline All Asia & 305420 & 253021 & 231503 & 185554 \\
\hline
\end{tabular}

${ }^{a}$ Data are in $\mathrm{kt}^{-1}$, excluding emissions from fossil fuel use for international aviation, international shipping, and open biomass burning.

b Streets et al. (2003) and http://www.cgrer.uiowa.edu/EMISSION_DATA/index_16.htm. CO emissions in China is the result of Streets et al. (2006).

c http://www.mnp.nl/edgar/model/v32ft2000edgar/

d http://www.iiasa.ac.at/rains/global_emiss/global_emiss1.html. Excluding Afghanistan.

IIASA one $(25.8 \mathrm{Mt})$, whereas the TRACE-P value $(22.7 \mathrm{Mt})$ was $10 \%$ lower, and that of EDGAR (31.1 Mt) $24 \%$ higher, than the REAS value. For Chinese $\mathrm{NO}_{\mathrm{x}}$ emissions (Table 7), the REAS value for $2000(11.2 \mathrm{Mt})$ was almost the same as the IIASA one $(11.7 \mathrm{Mt})$, whereas the TRACE-P value (10.5 Mt) was lower, and that of EDGAR (13.7 Mt) substan- tially higher, than the REAS and IIASA values. For Indian $\mathrm{NO}_{\mathrm{x}}$ emissions (Table 8), the REAS (4.7 Mt) and IIASA (4.6 Mt) values were very close, whereas the TRACE-P value (4.0 Mt) was slightly lower, and the EDGAR $(6.3 \mathrm{Mt})$ value higher, than the REAS and IIASA values. 
Table 7. Comparison of estimates of Chinese emissions, 1995-2003 ${ }^{\mathrm{a}}$.

\begin{tabular}{|c|c|c|c|c|c|c|c|c|c|c|}
\hline & Study & 1995 & 1996 & 1997 & 1998 & 1999 & 2000 & 2001 & 2002 & 2003 \\
\hline \multicolumn{11}{|c|}{$\mathrm{SO}_{2}$} \\
\hline & SEPA & 23700 & 23000 & 22400 & 21100 & 18575 & 19951 & 19478 & 19266 & 21587 \\
\hline & Xue et al. (1998) & 23700 & & & & & & & & \\
\hline & RAINS-ASIA & 23800 & & & & & & & & \\
\hline & Klimont et al. (2001) & 20900 & & & & & & & & \\
\hline & Streets and Waldhoff $(2000)^{b}$ & 24724 & & & & & & & & \\
\hline & Streets et al. (2000) & 25852 & 26359 & 25110 & & & & & & \\
\hline & TRACE-P; Streets et al. (2003) & & & & & & 20300 & & & \\
\hline & IIASA & 24818 & & & & & 27711 & & & \\
\hline & EDGAR 3.2 & 34548 & & & & & 34197 & & & \\
\hline & REAS; this study & 27141 & 28395 & 27755 & 27638 & 26987 & 27555 & 29292 & 31932 & 36627 \\
\hline \multicolumn{11}{|c|}{$\mathrm{NOx}$} \\
\hline & Hao et al. (2002) & 11298 & 12035 & 11666 & 11184 & & & & & \\
\hline & Xue et al. (1998) & 10700 & & & & & & & & \\
\hline & Klimont et al. (2001) & 9700 & & & & & & & & \\
\hline & Streets and Waldhoff (2000) & 11295 & & & & & & & & \\
\hline & Streets et al. (2001a) & 11192 & & 12537 & & & & & & \\
\hline & TRACE-P; Streets et al. (2003) & & & & & & 10531 & & & \\
\hline & IIASA & 9907 & & & & & 11722 & & & \\
\hline & EDGAR 3.2 & 12361 & & & & & 13728 & & & \\
\hline & REAS; this study & 9305 & 9943 & 10003 & 10463 & 10740 & 11186 & 11765 & 12688 & 14488 \\
\hline \multicolumn{11}{|l|}{$\mathrm{BC}$} \\
\hline & Cao et al. (2006) & & & & & & 1396 & & & \\
\hline & Streets et al. (2001b) & 1267 & & & & & & & & \\
\hline & TRACE-P; Streets et al. (2003) & & & & & & 936 & & & \\
\hline & Bond et al. (2004) & & 1365 & & & & & & & \\
\hline & REAS; this study & 1394 & 1331 & 1250 & 1213 & 1149 & 1093 & 1100 & 1113 & 1137 \\
\hline \multicolumn{11}{|l|}{ OC } \\
\hline & Cao et al. (2006) & & & & & & 3815 & & & \\
\hline & TRACE-P; Streets et al. (2003) & & & & & & 2657 & & & \\
\hline & Bond et al. (2004) & & 2111 & & & & & & & \\
\hline & REAS; this study & 3189 & 3072 & 2919 & 2811 & 2685 & 2563 & 2580 & 2599 & 2624 \\
\hline
\end{tabular}

\section{$\mathrm{CO}$}

Streets and Waldhoff (2000)
TRACE-P; Streets et al. (2003)
Streets et al. (2006)
IIASA
EDGAR 3.2
REAS; this study

\begin{tabular}{rrrrrrrrrr}
10900 & & & & & & & & \\
& & & & & & & \\
& & & & & & & \\
73446 & & & & & & & 14170000 & & \\
88000 & & & & & & 75442 & & & \\
149386 & 148927 & 144974 & 143301 & 139187 & 137011 & 140642 & 146298 & 158267 \\
\hline
\end{tabular}

a Data are $\mathrm{kt}^{-1}$, excluding emissions from open biomass burning.

$\mathrm{b}$ Data including emissions from open biomass burning.

Thus, the differences among emission inventories (REAS, IIASA, TRACE-P, and EDGAR) were similar for $\mathrm{SO}_{2}$ and $\mathrm{NO}_{\mathrm{x}}$ emissions in Asia, China, and India: the values estimated by REAS were close to those of IIASA, whereas TRACE-P values were smaller, and EDGAR ones larger, than those of REAS and IIASA.

\subsubsection{BC}

Total emissions of BC in Asia were $2.73 \mathrm{Mt}$ in 2000 (Table 4), and emissions from China (1.09 Mt; 40\%) and India $(0.80 \mathrm{Mt} ; 29 \%)$ were dominant, as were the $\mathrm{SO}_{2}$ and $\mathrm{NO}_{\mathrm{x}}$ emissions. Domestic consumption of biofuel and coal was the dominant contributor of $\mathrm{BC}$ emissions $(80 \%-60 \%$ 
Table 8. Comparison of estimates of Indian emissions, 1995 and $2000^{\mathrm{a}}$.

\begin{tabular}{|c|c|c|c|c|c|c|c|c|c|c|}
\hline \multirow{2}{*}{ Study } & \multicolumn{2}{|c|}{$\mathrm{SO}_{2}$} & \multicolumn{2}{|c|}{ NOx } & \multicolumn{2}{|c|}{$\mathrm{BC}$} & \multicolumn{2}{|c|}{$\mathrm{OC}$} & \multicolumn{2}{|c|}{$\mathrm{CO}$} \\
\hline & 1995 & 2000 & 1995 & 2000 & 1995 & 2000 & 1995 & 2000 & 1995 & 2000 \\
\hline Garg et al. (2001) & 4640 & & 3460 & & & & & & & \\
\hline Reddy \& Venkataraman (2002a,b) ${ }^{\text {b }}$ & 433 & & & & 307 & & 692 & & & \\
\hline RAINS-ASIA & 5000 & & & & & & & & & \\
\hline Streets et al. (2001a) & 5610 & & 4500 & & & & & & & \\
\hline TRACE-P; Streets et al. (2003) & & 5462 & & 4047 & & 517 & & 2190 & & 51081 \\
\hline Parashar et al. (2005) ${ }^{c}$ & & & & & 830 & & 2270 & & & \\
\hline Bond et al. (2004) ${ }^{\mathrm{d}}$ & & & & & 483 & & 1362 & & & \\
\hline IIASA & 5171 & 5919 & 3470 & 4563 & & & & & 52850 & 46753 \\
\hline EDGAR 3.2 & 6484 & 7846 & 5347 & 6285 & & & & & 55099 & 58631 \\
\hline REAS; this study & 5238 & 6140 & 4377 & 4730 & 791 & 795 & 3093 & 3268 & 74942 & 79382 \\
\hline
\end{tabular}

a Data are $\mathrm{kt}^{-1}$, excluding emissions from open biomass burning.

b Base year is 1996-1998.

c Base year is 1995 (biofuels) and 1993-1994 (fossil fuels).

d Base year is 1996.

for biofuel and $20 \%$ for coal)(Table 5). For China, domestic combustion contributed $85 \%$ (43\% each for biofuel and coal), and this percentage of coal use was twice the Asian average. In India, domestic biofuel use is a huge contributor at $77 \%$ - larger than the Asian total $(60 \%)$ or the Chinese value (43\%).

The Asian total BC emissions estimated by REAS $(2.73 \mathrm{Mt})$ were $34 \%$ higher than those of TRACE-P $(2.02 \mathrm{Mt})$ (Table 6). However, more recent estimates of emissions for 1996 that were developed for global carbonaceous particle inventories by the same group (Bond et al., 2004; Streets et al., 2004) were $2.65 \mathrm{Mt}$ (central value), which corresponds to $2.88 \mathrm{Mt}$ for 1996 in REAS. The Chinese BC emissions in 2000 (Table 7) as estimated by REAS (1.09 Mt) were lower than those of Cao et al. (2006) (1.40 Mt) but slightly higher than those of TRACE-P (0.94 Mt). For Chinese emissions in 1996 (Table 7), the REAS value of 1.33 Mt agreed with that of $1.37 \mathrm{Mt}$ estimated by Bond et al. (2004). The Indian BC emissions for 2000 (Table 8$)$ as estimated by REAS $(0.80 \mathrm{Mt})$ were the same as those of Dickerson et al. (2002), which were based on the INDOEX (Indian Ocean Experiment) observations, but higher than those of TRACE-P $(0.52 \mathrm{Mt})$. For Indian emissions in about 1995 (Table 8), the REAS value of $0.79 \mathrm{Mt}$ is close to the $0.83 \mathrm{Mt}$ (central value; range 0.31 $1.94 \mathrm{Mt}$ ) estimated by Parashar et al. (2005), but higher than the values of $0.31 \mathrm{Mt}$ by Reddy and Venkataraman (2002b) and $0.48 \mathrm{Mt}$ (central value; range $0.31-1.04 \mathrm{Mt}$ ) by Bond et al. (2004). It should be noted that the estimated BC emissions are highly variable because of the large uncertainties in the emission factors.

\subsubsection{OC}

Total emissions of OC in Asia was 8.88 Mt in 2000 (Table 4). India at $3.27 \mathrm{Mt}(37 \%)$ was the largest emitter, followed by China at $2.56 \mathrm{Mt}(29 \%)$ : the Indian emissions were larger than the Chinese one, unlike the case for $\mathrm{SO}_{2}, \mathrm{NO}_{\mathrm{x}}$, and $\mathrm{BC}$. Domestic consumption was the dominant contributor of OC emissions (95\%), especially for biofuel use (90\%). In India, domestic biofuel use contributed a large proportion of the OC emissions (94\%). For Chinese emissions, domestic combustion contributed $97 \%$ ( $82 \%$ for biofuel and $15 \%$ for coal).

Asian total OC emissions as estimated by REAS ( $8.87 \mathrm{Mt})$ were $26 \%$ higher than those estimated by TRACE-P (7.04 Mt) (Table 6), owing to differences in coal consumption in the domestic sector (for which the REAS value was 1.5 times the TRACE-P one). In addition, more recent estimates of emissions for 1996 (Bond et al., 2004; Streets et al., 2004 ) were $2.80-9.18 \mathrm{Mt}$ (central value; $4.81 \mathrm{Mt}$ ); the upper value corresponded to the value for 1996 estimated by REAS (9.05 Mt; data not shown). The emission factors for residential biofuel and coal combustion used by Bond et al. (2004) were lower than those in REAS and TRACE-P.

The Chinese OC emissions in 2000 (Table 7) as estimated by REAS (2.56 Mt) were close to those of TRACE$\mathrm{P}(2.66 \mathrm{Mt})$ but much lower than those of Cao et al. (2006) $(3.82 \mathrm{Mt})$, whose industrial emission value $(1.12 \mathrm{Mt})$ was much higher than those of REAS and TRACE-P (both $0.03 \mathrm{Mt}$ ), as was the case with BC emissions. For 1996, the REAS emission value of $3.07 \mathrm{Mt}$ was higher than the $2.11 \mathrm{Mt}$ estimated by Bond et al. (2004). There were large differences in the OC/BC ratio between inventories for China 1.55 for Bond et al. (2004), 2.24 for REAS, 2.73 for Cao 

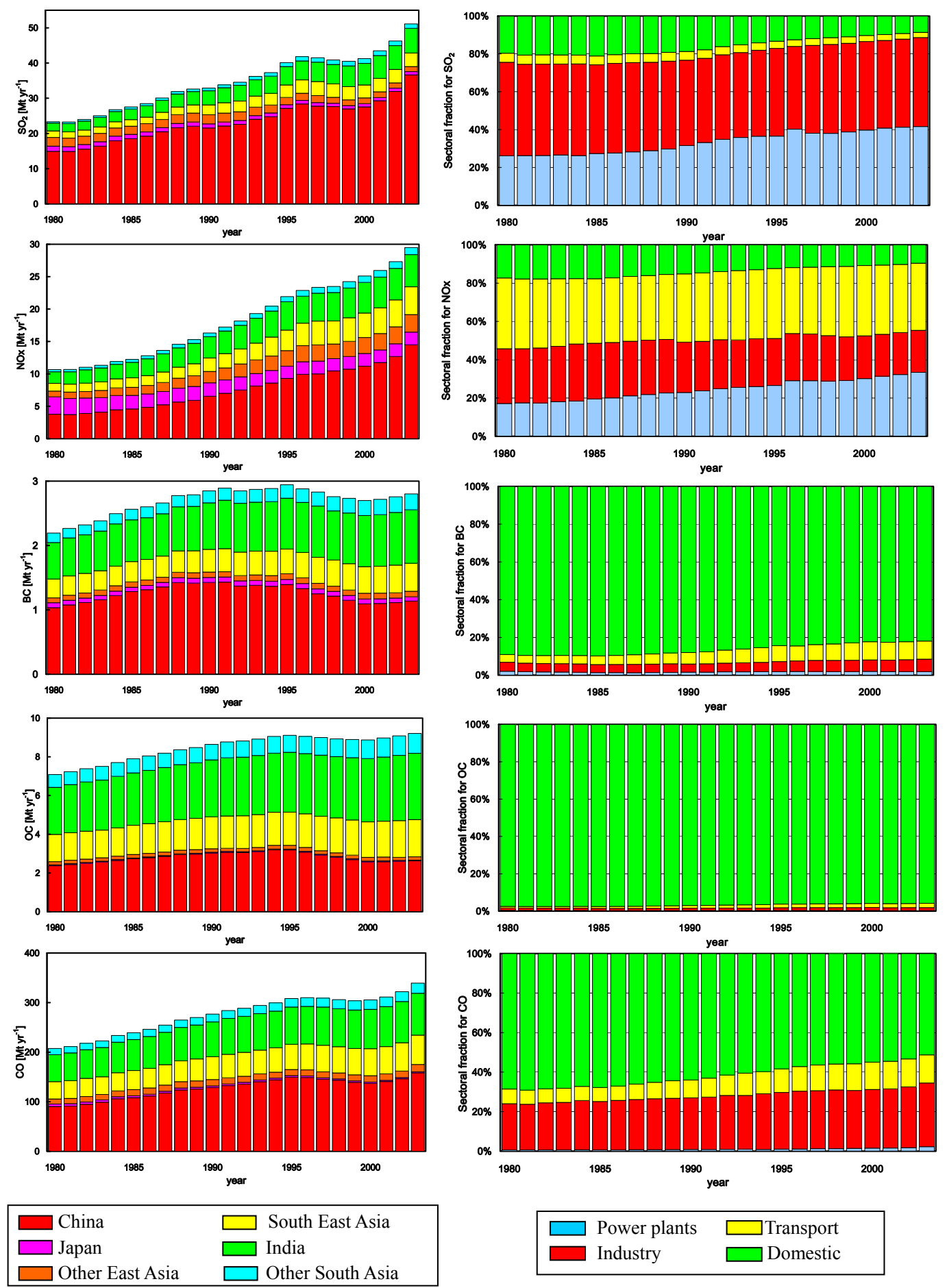

Fig. 4. Temporal evolution of emissions for $\mathrm{SO}_{2}, \mathrm{NO}_{\mathrm{x}}, \mathrm{BC}, \mathrm{OC}$, and $\mathrm{CO}$ and their sectoral distributions between 1980 and 2003.

et al. (2006), and 2.84 for TRACE-P - indicating that the emission factors for carbonaceous aerosols were highly uncertain. The discrepancy in the OC/BC ratio between REAS and TRACE-P was because there were large differences in the contribution of each fuel type in the domestic sector but only small differences in the emission factors in this sector. That is, fuel consumption in the domestic sector for REAS was 10.6 EJ (coal 3.1 EJ, biofuel 5.3 EJ, others 2.2 EJ) and that for TRACE-P was 10.6EJ (coal 2.4 EJ, biofuel 7.2 EJ, others $1.0 \mathrm{EJ}$ ). Thus, total consumption was the same, but 

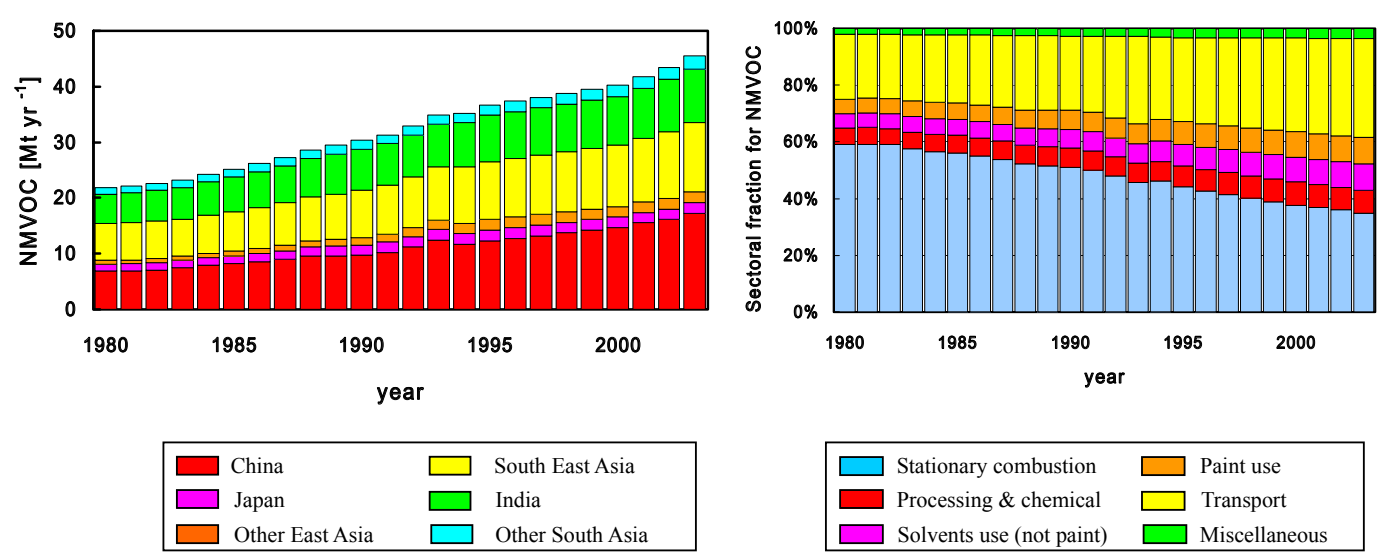

Fig. 5. Temporal evolution of NMVOC emissions and their sectoral distributions between 1980 and 2003.

each apportionment was quite different: for coal, the REAS value was larger than the TRACE-P one, whereas for biofuel the REAS value was smaller than the TRACE-P one. For $\mathrm{BC}$, the averaged emission factor for coal combustion was twice that for biofuel, whereas for OC that for biofuel was 3.5 times that for coal (see Table 3). Therefore, the value of $\mathrm{BC}$ emissions in REAS was higher than that in TRACE-P, whereas the value of OC emissions in REAS was lower than that in TRACE-P, and the resulting OC/BC ratio for REAS was lower than that in TRACE-P.

The Indian OC emissions in 2000 as estimated by REAS (3.27 Mt) (Table 8) were higher than that of TRACE-P $(2.19 \mathrm{Mt})$. This discrepancy was due to differences in biofuel consumption in the domestic sector: the REAS value was $20 \%$ larger than the TRACE-P one. For Indian emissions in about 1995, the REAS emission value of $3.09 \mathrm{Mt}$ was close to the upper value (range, 1.19-3.34 Mt) estimated by Parashar et al. (2005) but much higher than the $0.69 \mathrm{Mt}$ of Reddy and Venkataraman (2002b) and the $1.36 \mathrm{Mt}$ (central value; range $0.80-2.47 \mathrm{Mt}$ ) of Bond et al. (2004). This higher REAS value was a result of the high emission factor for biofuel in the residential sector; the value used in REAS $\left(5 \mathrm{~g} \mathrm{~kg}^{-1}\right)$ was close to the upper limit in Table 2 of Parashar et al. (2005).

\subsubsection{CO}

Total emissions of CO in Asia were $306 \mathrm{Mt}$ in 2000 (Table 4); China was the dominant country with $137 \mathrm{Mt}(45 \%)$, followed by India with $79 \mathrm{Mt}(26 \%)$. In terms of sectoral and fuel-type contribution (Table 5), domestic biofuel use was the largest $(48 \%)$, followed by industrial burned coal (19\%), transport oil use (14\%), and domestic coal use (7\%). Thus, CO emission sources, unlike those of other species, were distributed over many kinds of sector and/or fuel type. Contributors to Chinese $\mathrm{CO}$ emissions were industrial burned coal (35\%), biofuel and coal in the domestic sector (29\% and $13 \%)$, and transport oil use (14\%): the contribution of burned coal was higher than the average for Asia. In India, domestic biofuel use was the largest contributor $(71 \%)$, followed by industrial biofuel use and transport oil use (each 9\%).

The Asian CO emissions for 2000 as estimated by REAS (306 Mt) (Table 6) were higher than the values by TRACE-P (253 Mt), EDGAR (232 Mt), and IIASA (186 Mt) because of the application of higher emission factors for coal combustion in REAS. For Chinese CO emissions in 2000 (Table 7), the REAS value $(137 \mathrm{Mt})$ was similar to that of Streets et al. (2006) (142 Mt). However, there were large differences in sectoral emissions between REAS and Streets et al. (2006): emissions from the power plants, industry, transport, and domestic sectors were, respectively $2,57,19$, and $58 \mathrm{Mt}$ by REAS and 2, 54, 38, and $48 \mathrm{Mt}$ by Streets et al. (2006). Thus, the REAS value was higher in the domestic sector and lower in the transport sector than that of Streets et al. (2006). The Chinese CO emissions in REAS were consistent with the values for fossil fuel and biofuel combustion sources (145$168 \mathrm{Mt}$ ) estimated by top-down approaches such as inverse modeling (Palmer et al., 2003; Yumimoto and Uno, 2006) and forward modeling (Allen et al., 2004).

\subsection{Historical emissions between 1980 and 2003}

By using the activity data and emission factors described in Sects. 2.2 and 2.3, emissions of $\mathrm{SO}_{2}, \mathrm{NO}_{\mathrm{x}}, \mathrm{BC}, \mathrm{OC}$, and $\mathrm{CO}$, as well as NMVOC, were calculated for the period 19802003. Annual variations in regional emissions and the sectoral distributions of total emissions between 1980 and 2003 are shown in Fig. 4 for $\mathrm{SO}_{2}, \mathrm{NO}_{\mathrm{x}}, \mathrm{BC}, \mathrm{OC}$, and $\mathrm{CO}$, and in Fig. 5 for NMVOC. Table 9 shows the Asian and Chinese emissions at 5-year intervals in the period 1980-2003. Asian total emissions for every species increased by 1.3 times (for BC) to 2.8 times (for $\mathrm{NO}_{\mathrm{x}}$ ) from 1980-2003. Asian emissions for $\mathrm{SO}_{2}$ and $\mathrm{NO}_{\mathrm{x}}$, whose major sources are combustion facilities of fossil fuel, rapidly increased from 1980. NMVOC emissions also rapidly increased because of such factors as the growth of automobile use and solvent and paint 
Table 9. Asian and Chinese emissions, 1980-2003 ${ }^{\mathrm{a}}$.

\begin{tabular}{|c|c|c|c|c|c|c|c|c|c|c|c|c|}
\hline & & \multirow{2}{*}{$\frac{1980}{23338}$} & \multicolumn{2}{|c|}{1985} & \multicolumn{2}{|c|}{1990} & \multicolumn{2}{|c|}{1995} & \multicolumn{2}{|c|}{2000} & \multicolumn{2}{|c|}{2003} \\
\hline \multirow{6}{*}{ Asia $^{b}$} & $\mathrm{SO}_{2}$ & & 27681 & (1.19) & 33040 & $(1.42)$ & 40377 & $(1.73)$ & 41488 & $(1.78)$ & 51020 & (2.19) \\
\hline & $\mathrm{NOx}$ & 10676 & 12243 & (1.15) & 16316 & (1.53) & 21936 & (2.05) & 25112 & (2.35) & 29486 & $(2.76)$ \\
\hline & BC & 2194 & 2563 & (1.17) & 2850 & $(1.30)$ & 2944 & (1.34) & 2699 & $(1.23)$ & 2802 & $(1.28)$ \\
\hline & OC & 7083 & 7895 & (1.11) & 8644 & $(1.22)$ & 9109 & (1.29) & 8872 & (1.25) & 9205 & (1.30) \\
\hline & $\mathrm{CO}$ & 207388 & 239353 & (1.15) & 276734 & (1.33) & 308093 & (1.49) & 305420 & $(1.47)$ & 339399 & (1.64) \\
\hline & NMVOC & 21850 & 25144 & (1.15) & 30335 & (1.39) & 36671 & (1.68) & 40238 & $(1.84)$ & 45470 & $(2.08)$ \\
\hline \multirow{6}{*}{ China } & $\mathrm{SO}_{2}$ & 14944 & 18524 & $(1.24)$ & 21564 & $(1.44)$ & 27141 & $(1.82)$ & 27555 & $(1.84)$ & 36627 & (2.45) \\
\hline & NOx & 3774 & 4603 & $(1.22)$ & 6550 & (1.74) & 9305 & $(2.47)$ & 11186 & (2.96) & 14488 & (3.84) \\
\hline & $\mathrm{BC}$ & 1034 & 1283 & (1.24) & 1425 & (1.38) & 1394 & (1.35) & 1093 & (1.06) & 1137 & (1.10) \\
\hline & OC & 2370 & 2730 & (1.15) & 3020 & (1.27) & 3189 & (1.35) & 2563 & (1.08) & 2624 & (1.11) \\
\hline & $\mathrm{CO}$ & 90311 & 108228 & $(1.20)$ & 128354 & $(1.42)$ & 149386 & (1.65) & 137011 & $(1.52)$ & 158267 & (1.75) \\
\hline & NMVOC & 6826 & 8185 & $(1.20)$ & 9701 & $(1.42)$ & 12212 & $(1.79)$ & 14730 & $(2.16)$ & 17183 & $(2.52)$ \\
\hline
\end{tabular}

${ }^{a}$ Data are kt $\mathrm{y}^{-1}$. Numbers in parentheses are ratios to the 1980 values.

${ }^{\mathrm{b}}$ Excluding emissions from international aviation and international shipping.

use. The trend in carbonaceous particles (BC and $\mathrm{OC})$ emissions, whose major sources are biofuel combustion in the residential sector, showed small increases or fluctuations. The trend in $\mathrm{CO}$ emission showed the blended features of emissions for $\mathrm{SO}_{2}\left(\right.$ or $\mathrm{NO}_{\mathrm{x}}$ ) and carbonaceous particles. A detailed explanation of these features is presented in the following sections.

\subsection{1 $\quad \mathrm{SO}_{2}$}

Total emissions of $\mathrm{SO}_{2}$ in Asia increased from 1980 to 1996, but subsequently decreased till 1999, reflecting a decrease in fuel consumption due to the Asian economic crisis; after $2000 \mathrm{SO}_{2}$ emissions increased at a phenomenal rate. Those emissions increased by 2.2 times in the period 1980-2003, and, notably, by 3.2 times in India and 2.5 times in China. Examination of sectoral contributions in Asia revealed that the contribution of power plants increased from $28 \%$ in 1980 to $46 \%$ in 2003 . That of industry varied only slightly from $46 \%$ in 1980 to $42 \%$ in 2003 , and that of the domestic sector greatly decreased from $21 \%$ in 1980 to $9 \%$ in 2003.

We examined the time series of Chinese $\mathrm{SO}_{2}$ emissions in REAS, along with previous estimates (Fig. 6). Before 2000, the REAS variation corresponded to that of IIASA. The variation in SEPA (2003) was similar to that in REAS during 1986-1994, but about $7 \mathrm{Mt} \mathrm{y}^{-1}$ lower. In contrast, there were large differences between SEPA and REAS in the decreasing trend of $\mathrm{SO}_{2}$ emissions during 1995 and 2000, reflecting the differences in coal consumption in each inventory (Akimoto et al., 2006).

\subsection{2 $\quad \mathrm{NO}_{\mathrm{x}}$}

Total emissions of $\mathrm{NO}_{\mathrm{x}}$ in Asia (Table 9 and Fig. 4) showed a monotonic increase between 1980-2003 with no dips, in contrast to the pattern of $\mathrm{SO}_{2}$ emissions. The emissions in- creased by 2.8 times from 1980-2003, with values of $10.7 \mathrm{Mt}$ in 1980 and $29.5 \mathrm{Mt}$ in 2003. In particular, Chinese $\mathrm{NO}_{\mathrm{x}}$ emissions increased dramatically by 3.8 times from 1980 to 2003 - an annual-average growth rate of $6 \%$, with the highest growth after 2000 (by 1.3 times over only 3 years). Recently, these $\mathrm{NO}_{\mathrm{x}}$ trends in the period 1996-2003 over China were validated by comparison with column $\mathrm{NO}_{2}$ data from the GOME (Global Ozone Monitoring Experiment) satellite by Akimoto et al. (2006) and Uno et al. (2006). These trends in Chinese $\mathrm{NO}_{\mathrm{x}}$ emissions in REAS were consistent with those in other inventories, including IIASA, TRACE-P, and Hao et al. (2002) (Fig. 6).

Examination of sectoral contributions to Asian $\mathrm{NO}_{\mathrm{x}}$ emissions revealed that emissions from the power plants, industry, transport, and domestic sectors contributed $17 \%, 29 \%, 37 \%$, and $17 \%$, respectively, in 1980 and $33 \%, 22 \%, 35 \%$, and $10 \%$, respectively, in 2003: thus, the contribution of power plants almost doubled between 1980 and 2003 .

\subsubsection{BC}

Total BC emissions in Asia increased by 1.3 times over the period 1980-2003 (Table 9 and Fig. 4). However, the complexity of the temporal variation in this period was relatively large: emissions increased from 1980 to 1991, but subsequently were almost constant or slightly decreased till 2000; after 2000 they increased again. These complicated variations are reflected by those of the Chinese emissions. In China, the trend in total $\mathrm{BC}$ emissions is controlled by the balance between a decreasing rate of emissions from coal and biofuel combustion in the domestic sector and an increasing rate of emissions from coal-burning sources in the industrial sector and diesel vehicles. Examination of sectoral contributions showed that the contribution of the domestic sector decreased from $89 \%$ in 1980 to $82 \%$ in 2003 owing to the trend toward upgrading fuel quality from biofuels and coals 

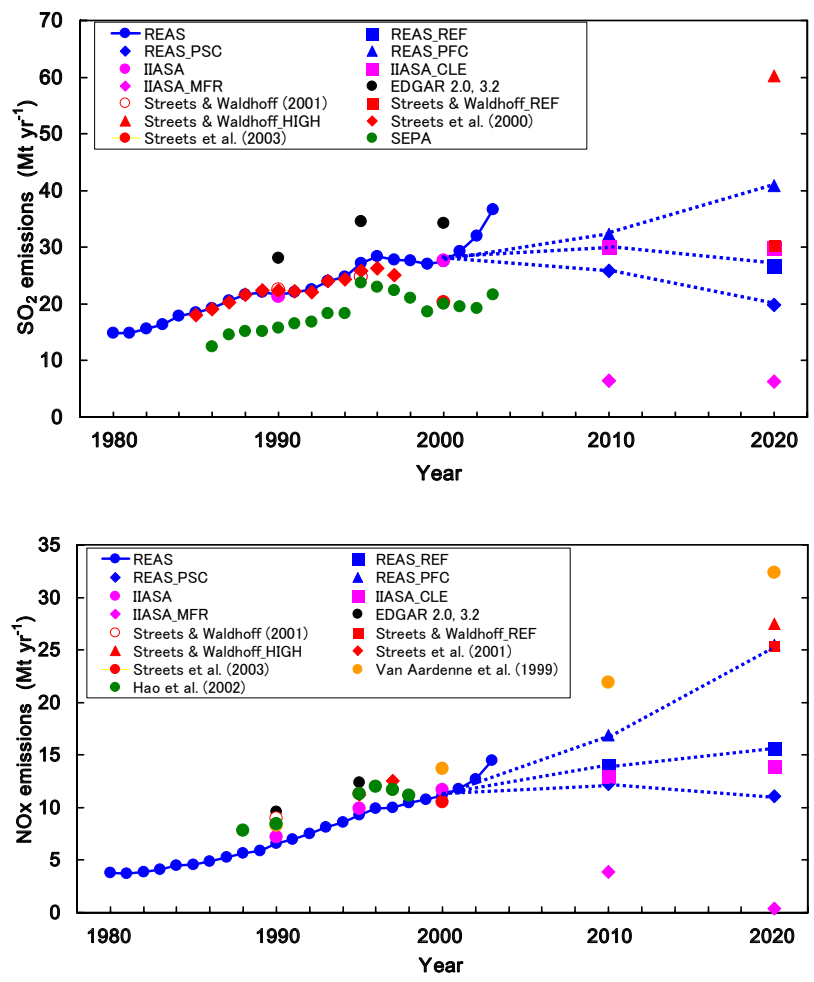

Fig. 6. Time series of $\mathrm{SO}_{2}$ and $\mathrm{NO}_{\mathrm{x}}$ emissions in China.

(as mentioned below), whereas that of transport sector increased from $4 \%$ in 1980 to $10 \%$ in 2003 because of the increase in the use of diesel vehicles.

The increase in BC emissions from 1980 to 2000 in South Asia, including India, was highest (1.5 times; data not shown), but that in China was comparatively small (1.1 times). Accordingly, there was a large difference between India and China in the changes in spatial distribution of $\mathrm{BC}$ emissions (see Fig. 8 in Sect. 3.4). In China, coal and biofuel combustion in the domestic sector is the dominant contributor to BC emissions (see Table 5). Total fuel consumption in the domestic sector increased from 8.4 EJ in 1980 to $10.6 \mathrm{EJ}$ in 2000, whereas the contributions of coal and biofuel to total fuels decreased. As a result, total consumption (7.9 EJ) of coal and biofuel in 2000 was almost the same as that in 1980 (7.8 EJ; see Table 2). This caused a small increase in BC emissions in China. On the other hand, in India, only biofuel combustion in the domestic sector was the dominant contributor to BC emissions (see Table 5). Biofuel consumption in the domestic sector in India increased from 5.9 EJ in 1980 to 7.9 EJ in 2000, and its contribution in the period 1980-2000 was maintained at around $90 \%$ (91\% for 1980 and $86 \%$ for 2000; see Table 2). Consequently, Indian BC emissions continued to increase throughout the period, unlike Chinese BC emissions.

\subsubsection{OC}

Total OC emissions in Asia increased by 1.3 times in the period 1980-2003 (Table 9 and Fig. 4), and the temporal variations were very similar to those of BC. Biofuel combustion in the domestic sector was the dominant contributor to $\mathrm{OC}$ emissions in both China and India (see Table 5). Biofuel consumption in China increased until 1995, and then slightly decreased or was uniform, whereas that in India continued to increase. As a result, although the value of OC emissions in India was almost the same as that in China before 1995, the former was higher than the latter after 1996. Consequently, the contrast between India and China in the changes in spatial distributions of $\mathrm{OC}$ emissions was similar to, but clearer than, that for BC (see Fig. 8 in Sect. 3.4).

The $\mathrm{OC} / \mathrm{BC}$ ratio in emissions varies widely throughout Asia, depending on the biofuel share of total fuels in the domestic sector. For example, the averaged OC/BC ratio in the period 1980-2003 was almost 2.3 (2.29 in 1980 and 2.31 in 2003) in China, but it was higher at almost 4.2 (4.29 for 1980 and 4.12 for 2003) in India because of the higher share of biofuel. Additionally, a clear contrast in the regional OC/BC ratio was also found within China: the ratio in southern areas of China was higher than that in northern areas, reflecting the higher share of coal and lower share of biofuel in northern areas. It should be noted that these spatial and temporal variations in $\mathrm{OC} / \mathrm{BC}$ ratio play an important role in the radiative effects of these aerosols over Asia.

\subsubsection{CO}

Total emissions for $\mathrm{CO}$ in Asia increased by 1.6 times in the period 1980-2003 (Table 9 and Fig. 4). The variation was similar to that of $\mathrm{SO}_{2}$ and was reflected by that of Chinese $\mathrm{CO}$ emissions, whose value was the largest in Asia, whereas $\mathrm{CO}$ emissions in India, which had the second-highest emission rate in Asia, continued to increase throughout the period. For China, CO emissions increased by 1.8 times from 1980 to 2003 , but they decreased from 1995-2000 owing to a reduction in consumption of coal and biofuel in the domestic sector in this period. Examination of sectoral contributions to Asian $\mathrm{CO}$ emissions revealed that the contribution of industry increased from $23 \%$ in 1980 to $32 \%$ in 2003, and that of transport increased from $7 \%$ in 1980 to $14 \%$ in 2003 . That of the domestic sector decreased from $69 \%$ in 1980 to $51 \%$ in 2003.

\subsubsection{NMVOC}

Total emissions of NMVOC in Asia showed a monotonic increase over the years 1980-2003 with no dip (Table 9 and Fig. 5), and the fundamental features of variation were similar to those for $\mathrm{NO}_{\mathrm{x}}$. Asian emissions increased by 2.1 times during the same period, especially in China, which had an increase of 2.5 times. Stationary combustion, processing and 
handling of fossil fuels and chemical industry ("Processing \& chemical" in Fig. 5), solvent use (excluding paint), paint use, transport, and miscellaneous contributed 59\%, 6\%, 5\%, 5\%, $23 \%$, and $2 \%$, respectively, to the total Asian NMVOC emissions in 1980 , and $35 \%, 8 \%, 9 \%, 9 \%, 35 \%$, and $4 \%$, respectively, in 2003: thus, examination of sectoral contributions showed a decrease for stationary combustion, a small increase for processing and handling of fossil fuels and chemical industry, and an increase for solvent and paint use and transport.

\subsection{Projection of future emissions}

Here, we briefly summarize the projected emissions of $\mathrm{SO}_{2}$, $\mathrm{NO}_{\mathrm{x}}, \mathrm{BC}, \mathrm{OC}, \mathrm{CO}$, and NMVOC in 2010 and 2020 (Table 10 and Fig. 7).

\subsection{1 $\quad \mathrm{SO}_{2}$}

Chinese $\mathrm{SO}_{2}$ emissions in the REF scenario showed a 9\% increase (to $30.0 \mathrm{Mt}$ ) for 2010 and a $3 \%$ decrease (to $26.8 \mathrm{Mt}$ ) for 2020 compared with 2000 (27.6 Mt). Although $\mathrm{SO}_{2}$ emissions in China were significantly reduced from $2000 \mathrm{lev}$ els in the PSC scenario (by 6\% in 2010 and $28 \%$ in 2020), the PFC scenario showed an increase of $17 \%$ in 2010 and $48 \%$ in 2020 over the 2000 level.

Consequently, Asian total $\mathrm{SO}_{2}$ emissions are strongly influenced by the emission scenario in China. The future total Asian emissions for $\mathrm{SO}_{2}$ under the REF scenario for China were projected to increase by $16 \%$ (to $47.9 \mathrm{Mt}$ ) in 2010 and $22 \%$ (to $50.2 \mathrm{Mt}$ ) in 2020 over the 2000 level $(41.2 \mathrm{Mt}$ ). Asian 2020 emissions under the PSC scenario for China were estimated to be $43.3 \mathrm{Mt}$, showing only a small increase (by $5 \%$ ) compared with the 2000 level, whereas the PFC scenario for China showed a rapid increase in Asian 2020 emissions: by $55 \%$ compared with the 2000 level.

$\mathrm{SO}_{2}$ emissions in East Asia excluding China (sum of values for Japan and other East Asia in Table 10) were projected to increase by $41 \%$ from 2000 (2.6 Mt) to 2020 (3.6 Mt). In Southeast Asia, $\mathrm{SO}_{2}$ emissions would double between 2000 $(3.6 \mathrm{Mt})$ and 2020 (7.1 Mt). Indian and other South Asian $\mathrm{SO}_{2}$ emissions in 2020 were estimated to be $10.2 \mathrm{Mt}$ and $2.5 \mathrm{Mt}$, respectively, showing a rapid growth in emissions (by $66 \%$ in India and $91 \%$ in other South Asia) compared with the 2000 level.

\subsection{2 $\quad \mathrm{NO}_{\mathrm{x}}$}

In China, future $\mathrm{NO}_{\mathrm{x}}$ emissions under the REF scenario were projected to increase by $25 \%$ (to $14.0 \mathrm{Mt}$ ) in 2010 and by $40 \%(15.6 \mathrm{Mt})$ in 2020 , compared with 2000 emissions $(11.2 \mathrm{Mt})$. There was a marked difference between $\mathrm{NO}_{\mathrm{x}}$ projections under the PSC and PFC scenarios. Under the PSC scenario, $2020 \mathrm{NO}_{\mathrm{x}}$ emissions were projected to be $11.1 \mathrm{Mt}$, but the PFC projection was more than twice as large at 25.5 Mt. Although the 2020 PSC scenario showed a slight reduction in emissions (1\%) compared with the 2000 level, the 2020 PFC scenario projected a marked increase of $128 \%$ over the 2000 level.

Asian total emissions for $\mathrm{NO}_{\mathrm{x}}$ under the REF scenario for China were projected to increase by $24 \%$ (to $31.1 \mathrm{Mt}$ ) in 2010 and 44\% (36.1 Mt) for 2020 over 2000 values (25.1 Mt). Asian 2020 emissions under the PSC scenario for China were estimated to be $31.6 \mathrm{Mt}$, a modest increase (by $26 \%$ ) compared with the 2000 level, whereas the PFC scenario for China showed a rapid increase in Asian 2020 emissions (to $46.0 \mathrm{Mt}$ ), by $83 \%$ compared with the 2000 level.

$\mathrm{NO}_{\mathrm{x}}$ emissions in East Asia excluding China were projected to increase by $24 \%$ from 2000 (4.4 Mt) to 2020 $(5.5 \mathrm{Mt})$. In Southeast Asia, $\mathrm{NO}_{\mathrm{x}}$ emissions would increase by $53 \%$ from $3.8 \mathrm{Mt}$ in 2000 to $5.8 \mathrm{Mt}$ in 2020 . Indian and other South Asian $\mathrm{NO}_{\mathrm{x}}$ emissions in 2020 were estimated at 7.1 Mt and 2.2 Mt, respectively - a rapid growth in emissions (by $49 \%$ in India and $122 \%$ in other South Asia) compared with 2000 levels.

\subsubsection{BC}

Under the REF scenario, 2010 BC emissions in China $(1.11 \mathrm{Mt})$ would be almost equal to those in 2000 (1.09 Mt) and would then decrease by $17 \%$ (to $0.91 \mathrm{Mt}$ ) by 2020 , owing to the reduction in coal and biofuel consumption in the domestic sector. Under the PSC scenario, Chinese BC emissions would be markedly reduced from 2000 levels (by $11 \%$ in 2010 and $40 \%$ in 2020). On the other hand, the PFC scenario showed an increase of $19 \%$ (in 2010) and $29 \%$ (in 2020) compared with the 2000 level because the increase in coal combustion will exceed the decrease in biofuel combustion in the domestic sector.

The future trend in Asian total $\mathrm{BC}$ emissions depends on the emission scenario in China. Under the REF scenario for China, future BC emissions in all of Asia would increase from the 2000 level $(2.70 \mathrm{Mt}$ ) by $16 \%$ (to $2.84 \mathrm{Mt}$ ) in 2010, and would then decline to about the 2000 level $(2.73 \mathrm{Mt})$ in 2020. Asian 2020 emissions under the PSC scenario for China were estimated to be $2.48 \mathrm{Mt}$, a decrease (by $8 \%$ ) compared with the 2000 level, whereas the PFC scenario for China gave an increase in Asian 2020 emissions of $20 \%$ over the 2000 level.

$\mathrm{BC}$ emissions in East Asia excluding China were projected to decline by $12 \%$ from $2000(0.16 \mathrm{Mt})$ to $2020(0.14 \mathrm{Mt})$ owing to the rapid reduction in Japan. In Southeast Asia, BC emissions would increase from 2000-2020, with $0.41 \mathrm{Mt}$ in 2000 and $0.46 \mathrm{Mt}$ in 2020. In India and other South Asia, $2020 \mathrm{BC}$ emissions were estimated to be $0.89 \mathrm{Mt}$ and $0.34 \mathrm{Mt}$, respectively - a modest increase in emissions (12\% in India and 45\% in other South Asia) compared with 2000 levels. 
Table 10. Summary of regional emissions in 2010 and $2020^{\mathrm{a}}$.

\begin{tabular}{|c|c|c|c|c|c|c|c|}
\hline Scenario & 2000 & 2010REF & 2010PSC & 2010PFC & 2020REF & 2020PSC & 2020PFC \\
\hline \multicolumn{8}{|c|}{$\mathrm{SO}_{2}$} \\
\hline China & 27555 & 29972 & 25864 & 32289 & 26804 & 19902 & 40863 \\
\hline Japan & 926 & 913 & - & - & 914 & - & - \\
\hline Other East Asia & 1642 & 2094 & - & - & 2698 & - & - \\
\hline Southeast Asia & 3649 & 5170 & - & - & 7062 & - & - \\
\hline India & 6140 & 7935 & - & - & 10192 & - & - \\
\hline Other South Asia & 1336 & 1849 & - & - & 2546 & - & - \\
\hline All Asia & 41248 & 47933 & 43825 & 50250 & 50216 & 43313 & 64275 \\
\hline \multicolumn{8}{|c|}{$\mathrm{NO}_{\mathrm{x}}$} \\
\hline China & 11186 & 13990 & 12253 & 16912 & 15619 & 11049 & 25469 \\
\hline Japan & 1959 & 1837 & - & - & 1837 & - & - \\
\hline Other East Asia & 2473 & 3069 & - & - & 3651 & - & - \\
\hline Southeast Asia & 3770 & 4800 & - & - & 5763 & - & - \\
\hline India & 4730 & 5900 & - & - & 7052 & - & - \\
\hline Other South Asia & 992 & 1496 & - & - & 2201 & - & - \\
\hline All Asia & 25112 & 31093 & 29355 & 34014 & 36124 & 31553 & 45973 \\
\hline \multicolumn{8}{|c|}{$\mathrm{BC}$} \\
\hline China & 1093 & 1107 & 975 & 1306 & 911 & 659 & 1415 \\
\hline Japan & 75 & 43 & - & - & 36 & - & - \\
\hline Other East Asia & 89 & 95 & - & - & 105 & - & - \\
\hline Southeast Asia & 413 & 447 & - & - & 456 & - & - \\
\hline India & 795 & 862 & - & - & 886 & - & - \\
\hline Other South Asia & 234 & 287 & - & - & 339 & - & - \\
\hline All Asia & 2699 & 2841 & 2709 & 3041 & 2733 & 2481 & 3237 \\
\hline \multicolumn{8}{|c|}{$\mathrm{OC}$} \\
\hline China & 2563 & 2187 & 1967 & 2549 & 1378 & 920 & 2214 \\
\hline Japan & 44 & 35 & - & - & 33 & - & - \\
\hline Other East Asia & 197 & 208 & - & - & 218 & - & - \\
\hline Southeast Asia & 1833 & 1933 & - & - & 1897 & - & - \\
\hline India & 3268 & 3540 & - & - & 3633 & - & - \\
\hline Other South Asia & 967 & 1152 & - & - & 1289 & - & - \\
\hline All Asia & 8872 & 9055 & 8834 & 9416 & 8448 & 7991 & 9285 \\
\hline \multicolumn{8}{|c|}{$\mathrm{CO}$} \\
\hline China & 137011 & 144540 & 131417 & 174131 & 131031 & 103630 & 212032 \\
\hline Japan & 2661 & 1900 & - & - & 1846 & - & - \\
\hline Other East Asia & 12708 & 15312 & - & - & 18829 & - & - \\
\hline Southeast Asia & 54514 & 61762 & - & - & 68443 & - & - \\
\hline India & 79382 & 88708 & - & - & 95733 & - & - \\
\hline Other South Asia & 19145 & 23065 & - & - & 27227 & - & - \\
\hline All Asia & 305420 & 335286 & 322163 & 364878 & 343109 & 315708 & 424110 \\
\hline \multicolumn{8}{|c|}{ NMVOC } \\
\hline China & 14730 & 22424 & 20757 & 23611 & 35098 & 28971 & 38599 \\
\hline Japan & 1880 & 2153 & - & - & 2462 & - & - \\
\hline Other East Asia & 1859 & 2724 & - & - & 3789 & - & - \\
\hline Southeast Asia & 11091 & 14675 & - & - & 19104 & - & - \\
\hline India & 8638 & 11485 & - & - & 15744 & - & - \\
\hline Other South Asia & 2040 & 2835 & - & - & 3914 & - & - \\
\hline All Asia & 40238 & 56297 & 54630 & 57483 & 80112 & 73985 & 83613 \\
\hline
\end{tabular}

a Data are in $k t y^{-1}$. 

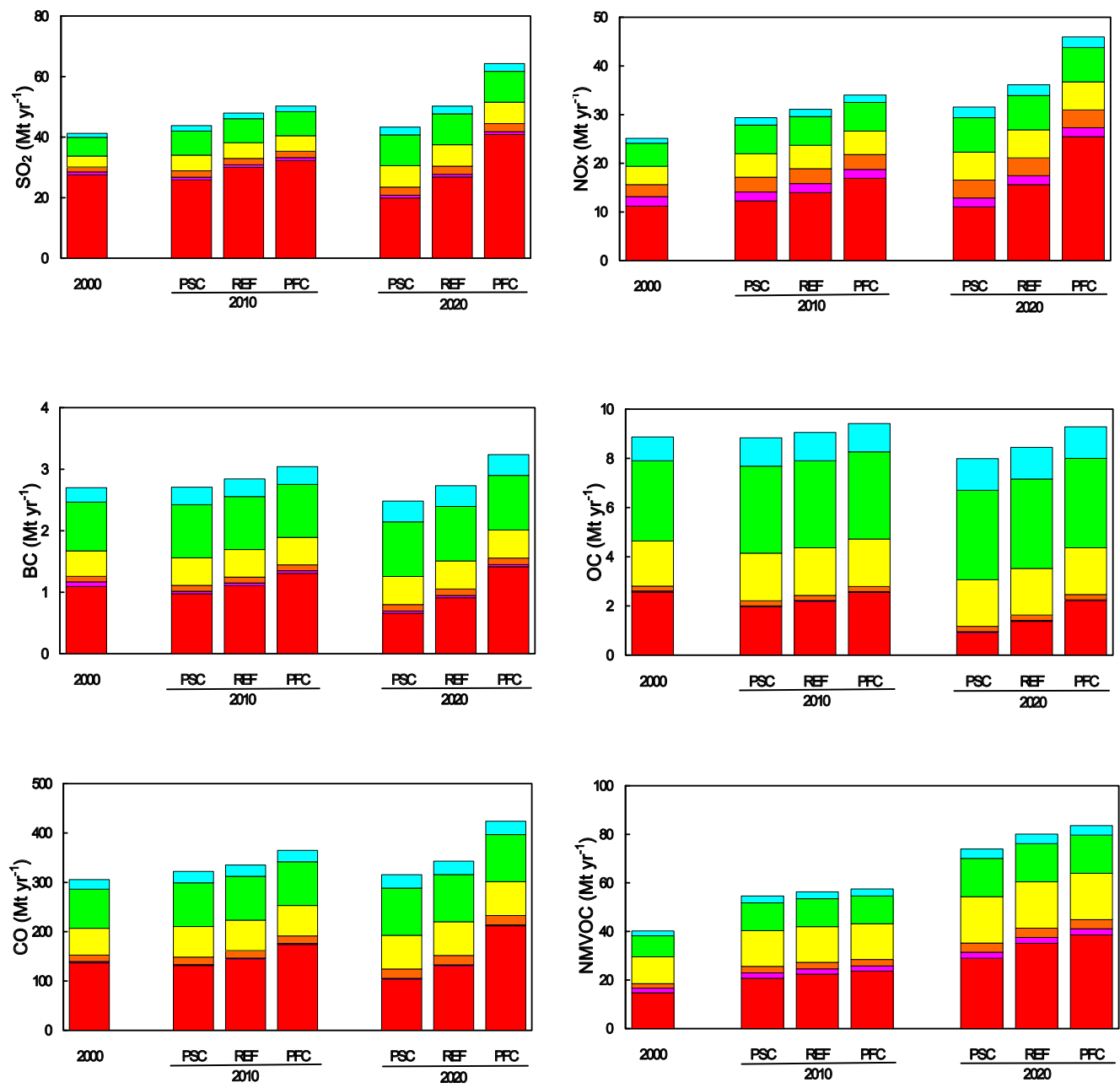

\begin{tabular}{|ll|}
\hline$\square$ China & $\square$ South East Asia \\
$\square$ Japan & $\square$ India \\
$\square$ Other East Asia & $\square$ Other South Asia \\
\hline
\end{tabular}

Fig. 7. Comparison of Asian emissions in 2000, 2010, and 2020.

\subsubsection{OC}

Chinese OC emissions in both 2010 and 2020 would decrease under any scenario compared with the 2000 level, owing to the decrease in biofuel consumption in the domestic sector. OC emissions in 2020 under the PSC, REF, and PFC scenarios were markedly reduced by $64 \%$ (to $0.92 \mathrm{Mt}$ ), $46 \%$ (to $1.38 \mathrm{Mt}$ ), and $14 \%$ (to $2.21 \mathrm{Mt}$ ), respectively, compared with the 2000 level $(2.56 \mathrm{Mt})$.

Total Asian 2020 OC emissions under the PSC, REF, and PFC scenarios in China were estimated to be $7.99 \mathrm{Mt}$, $8.45 \mathrm{Mt}$, and $9.29 \mathrm{Mt}$ - a $10 \%$ decrease, $5 \%$ decrease, and $5 \%$ increase, respectively, compared with 2000 emissions (8.87 Mt).
OC emissions in 2020 in East Asia excluding China were estimated to be $0.25 \mathrm{Mt}$ - almost equal to the 2000 emissions $(0.24 \mathrm{Mt})$. In Southeast Asia, India, and other South Asia, 2020 OC emissions showed increases $(4 \%, 11 \%$, and $33 \%$, respectively) compared with 2000 levels.

The $\mathrm{OC} / \mathrm{BC}$ ratio in China was projected to decrease from 2.3 in 2000 to 1.5 in the 2020 REF because of a marked reduction in $\mathrm{OC}$ but a modest reduction in $\mathrm{BC}$. On the other hand, the Indian OC/BC ratio in 2020 was projected to be the same as that in 2000 (almost 4.1). Consequently, the difference in the $\mathrm{OC} / \mathrm{BC}$ ratio between China and India would increase in future. 


\subsubsection{CO}

Under the REF scenario, $\mathrm{CO}$ emissions in China were projected to increase from $137 \mathrm{Mt}$ in 2000 to $145 \mathrm{Mt}$ in 2010, and then to decrease to $131 \mathrm{Mt}$ in 2020 (a 5\% increase in 2010 and a 4\% decrease in 2020 compared with the 2000 level). Although Chinese CO emissions under the PSC scenario were projected to decrease by $4 \%$ in 2010 and $28 \%$ in 2020 compared with 2000 emissions, the PFC scenario showed an increase in emissions (27\% in 2010 and $55 \%$ in 2020) over 2000 levels.

The future changes in Asian $\mathrm{CO}$ emissions were projected to be similar to those for $\mathrm{SO}_{2}$ emissions. Under the REF scenario for China, total Asian emissions were estimated to increase by $10 \%$ (to $335 \mathrm{Mt}$ ) and $12 \%$ (to $343 \mathrm{Mt}$ ) in 2010 and 2020, respectively, compared with the 2000 level (305 Mt). Under the PSC scenario for China, total Asian CO emissions were projected to increase by $5 \%$ (to $322 \mathrm{Mt}$ ) and $3 \%$ (to $316 \mathrm{Mt}$ ) in 2010 and 2020, respectively. Under the PFC scenario for China, total Asian CO emissions would increase by $19 \%$ (to $365 \mathrm{Mt}$ ) and $39 \%$ (to $424 \mathrm{Mt}$ ) in 2010 and 2020 , respectively.

$\mathrm{CO}$ emissions in East Asia excluding China were estimated to increase by $35 \%$ from $15 \mathrm{Mt}$ in 2000 to $21 \mathrm{Mt}$ in 2020. In Southeast Asia, 2020 CO emissions (68 Mt) should increase by $26 \%$ from $55 \mathrm{Mt}$ in 2000. CO emissions in India (and other South Asia) were projected to increase by $21 \%$ (42\%) from $79 \mathrm{Mt}(19 \mathrm{Mt})$ in 2000 to $96 \mathrm{Mt}(27 \mathrm{Mt})$ in 2020.

\subsubsection{NMVOC}

Under the REF scenario, 2020 NMVOC emissions in China (35.2 Mt) would rapidly increase by $139 \%$ from 2000 (14.7 Mt). Under the PSC and PFC scenarios, the 2020 NMVOC emissions in China would increase markedly by $97 \%$ and $163 \%$, respectively, compared with the 2000 level. Thus, Chinese NMVOC emissions were expected to rapidly at least double under any scenario, because the development of control technologies for anthropogenic NMVOC emissions would be behind those for other species. It should be noted that there were comparatively small differences between the values under the three kinds of scenarios. This shows that our assumptions of control technologies under each scenario (especially under the PSC scenario) may have been too conservative.

Under the REF scenario, total Asian NMVOC emissions were estimated to increase by $40 \%$ (to $56.3 \mathrm{Mt}$ ) and $100 \%$ (to $80.1 \mathrm{Mt}$ ) in 2010 and 2020, respectively, from 2000 (40.2 Mt). Under the PSC scenario, Asian NMVOC emissions were projected to increase by $36 \%$ (to $54.6 \mathrm{Mt}$ ) and $84 \%$ (74.0 Mt) in 2010 and 2020, respectively. Under the PFC scenario, Asian NMVOC emissions would increase by $43 \%$ (to $57.5 \mathrm{Mt}$ ) and $108 \%$ (to $83.6 \mathrm{Mt}$ ) in 2010 and 2020 , respectively.
NMVOC emissions in East Asia except China were estimated to increase by $67 \%$ from $3.7 \mathrm{Mt}$ in 2000 to $6.3 \mathrm{Mt}$ in 2020. NMVOC emissions in 2020 in Southeast Asia, India, and other South Asia were projected to be $72 \%, 82 \%$, and $92 \%$, respectively, higher than those in 2000.

\subsubsection{Comparison with other inventories}

Projected emissions depend strongly on the emission scenarios. In this section, the future emissions obtained by this study are compared with previous emission estimates for Asian countries: Van Aardenne et al. (1999), Streets and Waldhoff (2000), Streets et al. (2001b), Klimond et al. (2002), and Cofala et al. (2006).

Streets and Waldhoff (2000) projected $\mathrm{SO}_{2}, \mathrm{NO}_{\mathrm{x}}$, and $\mathrm{CO}$ emissions in China for 2020 by using two scenarios ([REF] and [HIGH]) and the emissions for 1990 and 1995. Their [REF] scenario was a "best guess" scenario, which means their best estimates of changes in emission factors and rates of deployment of emission control technologies and of new energy and process technologies, and their [HIGH] scenario was the most plausible upper estimates of emissions. $\mathrm{SO}_{2}$ emissions in China were projected to increase from 24.7 Mt in 1995 to $30.4 \mathrm{Mt}$ in the 2020 [REF] scenario, provided that emission controls are implemented on major power plants; if this does not happen, emissions could increase to as much as $60.2 \mathrm{Mt}$ under the 2020 [HIGH] scenario. The value of $\mathrm{SO}_{2}$ emissions under the 2020 [REF] scenario was close to the value in the 2020 REF scenario of REAS (26.8 Mt), whereas the 2020 [HIGH] scenario projected markedly higher emissions than those in the 2020 PFC scenario of REAS (40.9 Mt). Chinese $\mathrm{NO}_{\mathrm{x}}$ emissions were projected to increase from $11.3 \mathrm{Mt}$ in 1995 to $25.4 \mathrm{Mt}$ ([REF]) and $29.7 \mathrm{Mt}([\mathrm{HIGH}])$ in 2020 . This value in the 2020 [REF] scenario is almost the same as the value in the 2020 PFC scenario of REAS (25.5 Mt; see Table 10). Chinese $\mathrm{CO}$ emissions were projected to decline from $115 \mathrm{Mt}$ in 1995 to $96.8 \mathrm{Mt}$ in the 2020 [REF] scenario because of more efficient combustion techniques, especially in the transportation sector; if these measures are not realized, $\mathrm{CO}$ emissions could increase to $130 \mathrm{Mt}$ in the 2020 [HIGH] scenario. However, it should be noted that the Chinese CO emissions estimated by Streets and Waldhoff (2000) were extensively revised by Streets et al. (2006).

Recently, IIASA (Cofala et al., 2006; data available at: http://www.iiasa.ac.at/rains/global_emiss/global_emiss. html) developed emission scenarios by using the global version of the RAINS model (Amann et al., 1999) to project global atmospheric and climate change. They presented a set of global emission projections for $\mathrm{SO}_{2}, \mathrm{NO}_{\mathrm{x}}, \mathrm{CO}$, and $\mathrm{CH}_{4}$ during the period 1990-2030, and their emissions for 1990 and 2000 have been described in Sects. 3.1 and 3.2. For the future evolution of emission factors, two scenarios were proposed. One scenario was the "current legislation" ([CLE] scenario), which was characterized by the impacts of 
the emission control measures imposed by present legislation. An additional scenario was the "maximum technically feasible reduction" ([MFR] scenario), which included the levels of emission control offered by the full application of all the technical emission control measures that are presently available. We compared the changes between 2000 and 2020 for Asian $\mathrm{SO}_{2}$ and $\mathrm{NO}_{\mathrm{x}}$ emissions under the [CLE] scenario, which is more plausible than the [MFR] scenario, with those under the REAS scenarios. The change in Chinese $\mathrm{SO}_{2}$ emissions from 2000 to 2020 was projected to be an $8 \%$ increase under the [CLE] scenario and a $23 \%$ decrease, $3 \%$ decrease, and $48 \%$ increase under the PSC, REF, and PFC scenarios, respectively, of REAS. Thus, the $\mathrm{SO}_{2}$ emissions change in China under the [CLE] scenario was only slightly higher than those under the REF scenario. This feature of $\mathrm{SO}_{2}$ emissions is similar to that of the Indian emissions ([CLE]: 109\% increase, REF: $66 \%$ increase) and the Asian total emissions ([CLE]: $36 \%$ increase, REF: $22 \%$ increase). The change in Chinese $\mathrm{NO}_{\mathrm{x}}$ emissions between 2000 and 2020 was estimated to be an $18 \%$ increase under the [CLE] scenario, and a $1 \%$ decrease, $40 \%$ increase, and $128 \%$ increase under the PSC, REF, and PFC scenarios, respectively, of REAS. Therefore, the future change in Chinese $\mathrm{NO}_{\mathrm{x}}$ emissions under the [CLE] scenario would be higher than that under the PSC scenario but lower than that under the REF scenario. On the other hand, in India, the future change in $\mathrm{NO}_{\mathrm{x}}$ emissions under [CLE] (67\% increase) would be higher than that under the REF scenario (49\% increase), as with $\mathrm{SO}_{2}$ emissions. Asian total $\mathrm{NO}_{\mathrm{x}}$ emissions were projected to increase by $31 \%$ under the [CLE] scenario and by $26 \%, 44 \%$, and $83 \%$ under the PSC, REF, and PFC scenarios, respectively.

Van Aardenne et al. (1999) estimated $\mathrm{NO}_{\mathrm{x}}$ emissions for Asia in the period $1990-2020$ by using the RAINS-Asia methodology. For the projection of future emissions, an energy scenario based on a no-further-control ([NFC]) assumption was used. They reported that the $\mathrm{NO}_{\mathrm{x}}$ emissions in China and in all Asian countries would grow rapidly (by $290 \%$ and 350\%, respectively) during the period 1990-2020. The [NFC] scenario projected the same growth of Chinese $\mathrm{NO}_{\mathrm{x}}$ emissions as the PFC scenario (290\%) in the REAS inventory, but showed a doubling of growth in total Asian emissions under PFC (180\%).

Streets et al. (2001b) predicted that Chinese BC emissions would be reduced by $8 \%$ from $1.28 \mathrm{Mt}$ in 1995 to $1.17 \mathrm{Mt}$ in 2020 (emissions from open burning were excluded) because of the reduction in emissions from coal and biofuel combustion in the domestic sector. Our projections of Chinese BC emissions in 2020 were $0.66 \mathrm{Mt}$ (PSC), $0.91 \mathrm{Mt}$ (REF), and $1.42 \mathrm{Mt}$ (PFC) - changes from 1995 representing a $53 \%$ decrease, $35 \%$ decrease, and $2 \%$ increase, respectively. Thus, the growth rate from 1995 to 2020 reported by Streets et al. (2001b) was close to that under the PFC scenario.

Klimont et al. (2002) reported emission inventories for NMVOC in China for the years 1990-2020. They estimated that emissions could grow by $40 \%$ to $18.2 \mathrm{Mt}$ in 2020 from 13.1 Mt in 1995. On the other hand, our estimates showed a marked increase of $140 \%$ (PSC) to $220 \%$ (PFC) over the 1995 levels. The differences in emissions in the transport sector between the two inventories are important to note. Whereas transport emissions in 2020 were markedly increased over 1995 levels under the REAS scenario (e.g., by $350 \%$ under the REF scenario), Klimont et al. (2002) showed the same level as for the 1995 emissions. This may have been caused by differences in the future fuel consumption and/or emission controls for automobiles between the two inventories.

We compared the future emission trends in China according to several inventories (Fig. 6). The projected trends, of course, depend strongly on the emission scenarios provided by each researcher and reveal marked differences between projections, compared with the small differences between estimates for the years before 2000. For $\mathrm{SO}_{2}$ emissions, the REF scenario of REAS provided a projection for 2020 emissions that was similar to the [CLE] scenario of IIASA and to the [REF] scenario of Streets et al. (2000). On the other hand, the [HIGH] scenario of Streets et al. (2000) showed a marked increase compared with other projections (including the three REAS scenarios), but this highest trend may be a "best guess" estimate, considering the rapid growth of emissions after 2000. For $\mathrm{NO}_{\mathrm{x}}$ emissions, the scenario of Van Aardenne et al. (1999) gave an estimate at the top of the projection range, whereas the MFR scenario of IIASA projected a minimum value in the range. The REF scenario of REAS projected estimates in 2010 and 2020 similar to the [CLE] scenario of IIASA. Additionally, the PFC scenario of REAS estimated 2020 emissions that were similar to those of the $[\mathrm{REF}]$ and $[\mathrm{HIGH}]$ scenarios of Streets and Waldhoff (2000).

It should be noted from Fig. 6 that the dramatic growth after 2000 in $\mathrm{SO}_{2}$ and $\mathrm{NO}_{\mathrm{x}}$ emissions has overshot all of the projections. This means that every scenario, including ours, failed to project the recent growth in Chinese emissions. However, although the trend in Chinese $\mathrm{NO}_{\mathrm{x}}$ emissions in the period 1996-2003 was validated by Akimoto et al. (2006) using the column $\mathrm{NO}_{2}$ data from the GOME satellite, the recent growth in $\mathrm{SO}_{2}$ emissions has not been validated by satellite data and may be overestimated because the implementation of emission controls after 2000 was not taken into account. Additionally, it may be necessary to make projections on the basis of the emission inventories for more recent years because of the rapid growth in economic activity and energy consumption and the development of regulations for emission control after 2000.

\subsection{Gridded emissions}

We examined the geographical distribution of six species $\left(\mathrm{SO}_{2}, \mathrm{NO}_{\mathrm{x}}, \mathrm{BC}, \mathrm{OC}, \mathrm{CO}\right.$, and $\left.\mathrm{NMVOC}\right)$ at $0.5^{\circ} \times 0.5^{\circ}$ resolution under 1980, 2000, and 2020 REF (Fig. 8). The growth of $\mathrm{SO}_{2}$ emissions in China and India in the period 1980-2000 
is clearly shown, whereas the spatial distribution in 2000 is similar to that in $2020 \mathrm{REF}$. The growth in $\mathrm{NO}_{\mathrm{x}}$ emissions from 1980 to 2000 is more rapid than that of $\mathrm{SO}_{2}$ and is especially located in the coastal areas of China and on the Hindustan Plain and central west coast of India, as is the case for $\mathrm{SO}_{2} . \mathrm{NO}_{\mathrm{x}}$ emissions would continue to grow until at least 2020 under the REF scenario. On the other hand, $\mathrm{SO}_{2}$ and $\mathrm{NO}_{\mathrm{x}}$ emissions in Japan and South Korea have resulted in only small changes in the 40 years.

It is important to note the difference in the temporal variation of the spatial distributions of $\mathrm{BC}$ and $\mathrm{OC}$ emissions between China and India: the Chinese emission patterns indicate a small change from 1980 to 2000 and then a decrease until 2020, whereas the Indian emissions continue to increase from 1980 to 2020 . The main reason for this is that the trend in biofuel consumption for domestic use in China is quite different from that in India, as mentioned in Sects. 3.2 and 3.3. In China, domestic biofuel consumption did not vary with time before 2000 and was markedly reduced from 2000 levels under the 2020 REF scenario (by $42 \%$ ). On the other hand, consumption in India increased by 1.3 times in the period 1980-2000, and the 2020 scenario showed an increase of nearly $10 \%$ over 2000 levels.

A large growth in NMVOC emissions - as much as the growth of $\mathrm{NO}_{\mathrm{x}}$ emissions - was projected throughout Asia (Fig. 8). By 2020, under any of the REAS scenarios, it was projected that the growth rate of NMVOC emissions from 2000 would be higher than that of $\mathrm{NO}_{\mathrm{x}}$. The resulting Asian average $\mathrm{NMVOC} / \mathrm{NO}_{\mathrm{x}}$ ratio - a key indicator of photochemical reactivity - was 2.05 (in units of $\mathrm{g} / \mathrm{g}$ ) in both 1980 and 2000 ; it then increased to as much as $4.44(\mathrm{~g} / \mathrm{g})$ by 2020 under the REF scenario, proceeding to an $\mathrm{NO}_{\mathrm{x}}$-limited regime. Ozone concentrations increase with increasing $\mathrm{NO}_{\mathrm{x}}$ and are insensitive to NMVOC (Yamaji et al., 2007¹).

\section{Summary and conclusions}

We developed a Regional Emission Inventory in Asia (REAS version 1.1 ) with $0.5^{\circ} \times 0.5^{\circ}$ resolution. It includes a historical and present inventory for 1980-2003 and projects emissions till 2020 for $\mathrm{SO}_{2}, \mathrm{NO}_{\mathrm{x}}, \mathrm{CO}, \mathrm{NMVOC}, \mathrm{BC}$, and $\mathrm{OC}$ from fuel combustion and industrial sources.

Total energy consumption in Asia more than doubled between 1980 and 2003, causing a rapid growth in Asian emissions, by $28 \%$ for BC, $30 \%$ for OC, $64 \%$ for CO, $108 \%$ for NMVOC, $119 \%$ for $\mathrm{SO}_{2}$, and $176 \%$ for $\mathrm{NO}_{\mathrm{x}}$ over this period. In particular, Chinese $\mathrm{NO}_{\mathrm{x}}$ emissions showed a marked increase of $280 \%$ over 1980 levels, and $\mathrm{NO}_{\mathrm{x}}$ emissions growth after 2000 has been extremely high, as has been that of $\mathrm{SO}_{2}$

\footnotetext{
${ }^{1}$ Yamaji, K., Ohara, T., Uno, I., Kurokawa, J., and Akimoto, H.: Future prediction of surface ozone over East Asia using the Models3 Community Multi-scale Air Quality Modeling System (CMAQ) and the Regional Emission Inventory in Asia (REAS), J. Geophys. Res., submitted, 2007.
}

emissions. These increases in China are caused mainly by increases in coal combustion by power plants and the industrial sector. NMVOC emissions have also rapidly increased owing to the growth of automobile use and solvent and paint use. By contrast, EC, OC, and CO emissions in China decreased from 1996 to 2000 because of a reduction in the use of biofuels and coal in the domestic and industrial sectors. After 2000, Chinese emissions of these species began to increase. Thus the emission of air pollutants in Asian countries (especially China) showed large temporal variations in the period 1980-2003.

Future emissions in 2010-2020 are projected in Asian countries on the basis of the emission scenarios. For China, we developed three emission scenarios, PSC, REF, and PFC. Under the 2020 REF scenario, Asian total emissions for $\mathrm{SO}_{2}$, $\mathrm{NO}_{\mathrm{x}}$, and NMVOC were projected to increase substantially by $22 \%, 44 \%$, and $99 \%$, respectively, over 2000 levels. With regard to other species, the 2020 REF scenario showed a modest increase in $\mathrm{CO}(12 \%)$, a lesser increase in $\mathrm{BC}(1 \%)$, and a slight decrease in OC $(-5 \%)$ compared with 2000 levels. However, it should be noted that Asian total emissions are strongly influenced by the emission scenarios for China. Under the PFC scenario, the growth of emissions was expected to be greater, whereas the PSC scenario showed acceleration of the decrease, or deceleration of the increase, in emissions. For example, $\mathrm{SO}_{2}$ emissions in China were projected to increase from 27.6 Mt in 2000 to $30.0 \mathrm{Mt}$ in 2010 , and to then decrease to $26.8 \mathrm{Mt}$ in 2020 under the REF scenario; $\mathrm{SO}_{2}$ emissions in China were markedly reduced from 2000 levels under the PSC scenario (by 6\% in 2010 and 28\% in 2020) and the PFC scenario showed an increase of $17 \%$ in 2010 and $48 \%$ in 2020 over the 2000 level. Future total Asian emissions of $\mathrm{SO}_{2}$ under the REF scenario were projected to increase by $16 \%$ (to $47.9 \mathrm{Mt}$ ) in 2010 and $22 \%$ (50.2 Mt) in 2020 from 2000 (41.2 Mt). Asian 2020 emissions for $\mathrm{SO}_{2}$ were estimated to be $43.3 \mathrm{Mt}$ under the PSC scenario - only a small increase (by 5\%) compared with the 2000 level - whereas the PFC scenario showed a rapid 5\% increase in Asian 2020 emissions over the 2000 level. As with $\mathrm{SO}_{2}$, under the 2020 PFC scenario Asian total emissions for all another species were projected to increase, by $83 \%$ for $\mathrm{NO}_{\mathrm{x}}, 20 \%$ for $\mathrm{BC}, 5 \%$ for $\mathrm{OC}, 3 \%$ for $\mathrm{CO}$, and $108 \%$ for NMVOC, over 2000 levels, whereas the 2020 PSC scenario showed modest changes of $26 \%$ for $\mathrm{NO}_{\mathrm{x}},-8 \%$ for $\mathrm{BC},-10 \%$ for OC, and $3 \%$ for $\mathrm{CO}$, but an extreme change of $84 \%$ for NMVOC, compared with 2000 emissions. The fact that there are large variations depending on the emission scenario suggests that a series of emission controls needs to be implemented in Asian countries - especially in China and India - to prevent deterioration of the air quality in Asia.

Further research on the emission characterization of small and/or old-fashioned sources and on the recent progress of emission control in each country, together with the use of a top-down approach that combines field and satellite measurements and forward/inverse modeling with emission inventory 

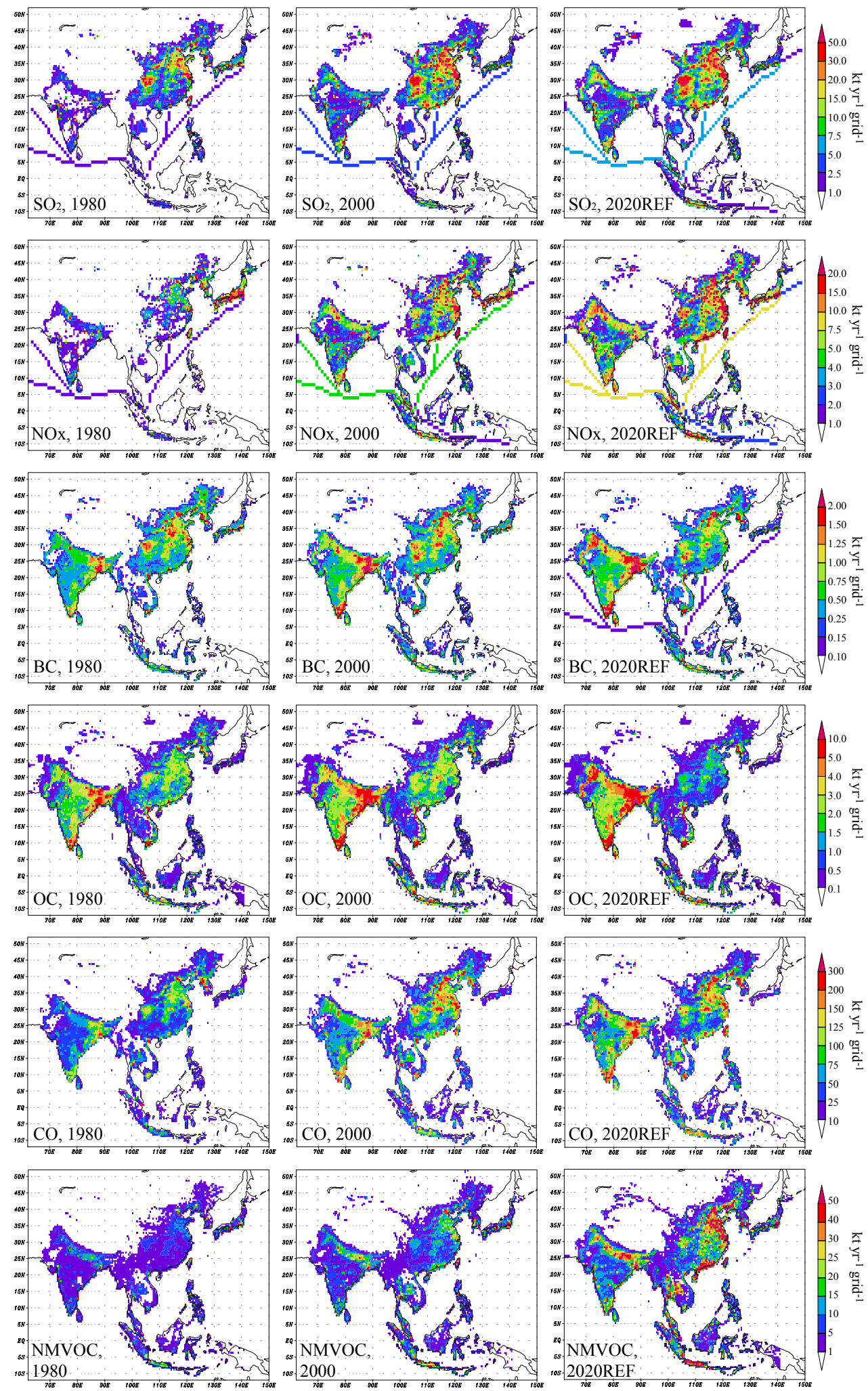

Fig. 8. Spatial distributions of emissions of $\mathrm{SO}_{2}, \mathrm{NO}_{\mathrm{x}}, \mathrm{BC}, \mathrm{OC}, \mathrm{CO}$, and $\mathrm{NMVOC}$ at $0.5^{\circ} \times 0.5^{\circ}$ resolution in 1980,2000 , and 2020 under the REF scenario. 
development, will be required to reduce the uncertainty in the estimation of emissions.

Acknowledgements. This study was supported by the Global Environment Research Fund of the Ministry of the Environment, Japan (B-051); a RR2002 grant from the Ministry of Education, Culture, Sports, Science and Technology, Japan; and a Grant-in-Aid for Scientific Research from the Japan Society for the Promotion of Science (15310011). We would like to thank D. Streets (Argonne National Laboratory) for providing the NMVOC emissions data set and other information for our emissions estimates. We thank K. He (Tsinghua University) for providing country-specific data and information on Chinese emissions, D. Zhou (Energy Research Institute, China) for providing projected energy consumptions in China, and $\mathrm{H}$. Tian (Beijing Normal University) for valuable comments on Chinese emissions.

Edited by: M. Dameris

\section{References}

Akimoto, $\mathrm{H}$. and Narita, $\mathrm{H}$.: Distribution of $\mathrm{SO}_{2}, \mathrm{NO}_{\mathrm{x}}$, and $\mathrm{CO}_{2}$ emissions from fuel combustion and industrial activities in Asia with $1^{\circ} \times 1^{\circ}$ resolution, Atmos. Environ., 28, 213-225, 1994 .

Akimoto, H.: Global air quality and pollution, Science, 302, 17161719, 2003.

Akimoto, H. and Ohara, T.: Asian Inventories, in: Emissions of Atmospheric Trace Compounds, edited by: Granier, C., Artaxo, P., Reeves, C. E., Kluwer Academic Publishers, Dordrecht/Boston/London, 47-53, 2004.

Akimoto, H., Ohara, T., Kurokawa, J., and Horii, N.: Verification of energy consumption in China during 1996-2003 by satellite observation, Atmos. Environ., 40, 7663-7667, 2006.

Allen, D., Pickering, K., and Fox-Rabinovitz, M.: Evaluation of pollutant outflow and CO sources during TRACE-P using modelcalculated, aircraft-based, and Measurements of Pollution in the Troposphere (MOPITT)-derived CO concentrations, J. Geophys. Res., 109, D15S03, doi:10.1029/2003JD004250, 2004.

Amann, M., Bertok, I., Cofala, J., Gyarfas, F., Heyes, C., Klimont, Z., Makowski, M., Schoopp, W., and Syri, S.: Cost-effective control of acidification and ground-level ozone, Seventh Interim Report, International Institute for Applied Systems Analysis, Laxenburg, Austria, 1999.

Bond, T. C., Streets, D. G., Yarber, K. F., Nelson, S. M., Woo, J.H., and Klimont, Z.: A technology-based global inventory of black and organic carbon emissions from combustion, J. Geophys. Res., 109, D14203, doi:10.1029/2003JD003697, 2004.

Cao, G., Zhang, X., and Zheng, F.: Inventory of black carbon and organic carbon emissions from China, Atmos. Environ., 40, 6516-6527, 2006.

Cass, G. R., Boone, P. M., and Macias, E. S.: Emissions and air quality relationships for atmospheric carbon particles in Los Angeles, in: Particulate carbon - atmospheric life cycle, edited by: Wolff, G. T. and Klimisch, R. L., Plenum, New York, 207-240, 1982.

Cofala, J., Amann, M., and Mechler, R.: Scenarios of world anthropogenic emissions of air pollutants and methane up to 2030, Interim Report IR-06-023, available at: http://www.iiasa.ac.at/ rains/global_emiss/global_emiss.html, 2006.
Dickerson, R. R., Andreae, M. O., Campos, T., Mayol-Bracero, O. L., Neusuess, C., and Streets, D. G.: Analysis of black carbon and carbon monoxide observed over the Indian Ocean: implications for emissions and photochemistry, J. Geophys. Res., 107, 8017, doi:10.1029/2001JD000501, 2002.

Downing, R. J., Ramankutty, R., and Shah, J. J.: Rains-Asia: An assessment model for acid deposition in Asia, The World Bank, Washington, D.C., 1997.

EEA (European Environment Agency): EMEP/CORINAIR Emission Inventory Guidebook, Copenhagen, available at: http: //reports.eea.europa.eu/EMEPCORINAIR3/en/page002.html/, 2000.

FAO (Food and Agriculture Organization): FAO Statistical Database, United Nations Food and Agriculture Organization, Rome, available at: http://www.fao.org, 2000.

Garg, A., Shukla, P. R., Bhattacharya, S., and Dadhwal, V. K.: Subregion (district) and sector level $\mathrm{SO}_{2}$ and $\mathrm{NO}_{\mathrm{x}}$ emissions for $\mathrm{In}-$ dia: assessment of inventories and mitigation flexibility, Atmos. Environ., 35, 703-713, 2001.

Hao, J., Tian, H., and Lu, Y.: Emission inventories of $\mathrm{NO}_{\mathrm{x}}$ from commercial energy consumption in China, 1995-1998, Environ. Sci. Technol., 36, 552-560, 2002.

IEA (International Energy Agency): World energy outlook, IEA, Paris, 2002.

IEA (International Energy Agency): Energy statistics of OECD countries and energy statistics of non-OECD countries, IEA, Paris, 2004.

IIASA (International Institute for Applied Systems Analysis): RAINS-ASIA CD-ROM Version 7.52, Laxenburg, Austria, 2001.

IPCC (Intergovernmental Panel on Climate Change): Revised 1996 IPCC guidelines for national greenhouse gas inventories, edited by: Houghton, J. T., Meira Filho, L. G., Lim, B., Treanton, K., et al., IPCC WGI Technical Support Unit, Bracknell, UK, 1997.

Irie, H., Sudo, K., Akimoto, H., Richter, A., Burrows, J. P., Wagner, T., Wenig, M., Beirle, S., Kondo, Y., Sinyakov, V. P., and Goutail, F.: Evaluation of long-term tropospheric $\mathrm{NO}_{2}$ data obtained by GOME over East Asia in 1996-2002, Geophys. Res. Lett., 32, L11810, doi:10.1029/2005GL022770, 2005.

Minato, K.: Improving urban air quality in Asia, JARI (Japan Automobile Research Institute) Research Journal, 24, 477-481 [in Japanese], 2002.

Kannari, K., Tonooka, Y., Baba, T., and Murano, K.: Development of multiple-species $1 \mathrm{~km} \times 1 \mathrm{~km}$ resolution hourly basis emissions inventory for Japan, Atmos. Environ., 41, 3428-3439, 2007.

Kato, N., Ogawa, Y., Koike, T., Sakamoto, T., and Sakamoto, S.: Analysis of the structure of energy consumption and the dynamics of emissions of atmospheric species related to the global environmental change $\left(\mathrm{SO}_{\mathrm{x}}, \mathrm{NO} \& \mathrm{CO}\right)$ in Asia, NISTEP Report No. 21, National Institute of Science and Technology Policy, Japan, 1991.

Kato, N. and Akimoto, H.: Anthropogenic emissions of $\mathrm{SO}_{2}$ and $\mathrm{NO}_{\mathrm{x}}$ in Asia: emissions inventories, Atmos. Environ., 26, 2997 3017, 1992.

Klein Goldewijk, C. G. M. and Battjes, J. J.: A hundred year (1890-1990) database for integrated environmental assessments (HYDE, version 1.1), Report no. 422514002, National Institute of Public Health and the Environment (RIVM), Bilthoven, The Netherlands, 1997. 
Klimont, Z., Cofala, J., Schopp, W., Amann, M., Streets, D. G., Ichikawa, Y., and Fujita, S.: Projection of $\mathrm{SO}_{2}, \mathrm{NO}_{\mathrm{x}}, \mathrm{NH}_{3}$ and VOC emissions in East Asia up to 2030, Water Air Soil Poll., 130, 193-198, 2001.

Klimont, Z., Streets, D. G., Gupta, S., Cofala, J., Fu, L., and Ichikawa, Y.: Anthropogenic emissions of non-methane volatile organic compounds in China, Atmos. Environ., 36, 1309-1322, 2002.

Nakicenovic, N. J. and Swart, R. (Eds.): IPCC special report on emissions scenarios, Cambridge University Press, Cambridge, United Kingdom and New York, NY, 2000.

National Bureau of Statistics: China energy statistical yearbook (1991-1996, 1997-1999, 2000-2002, 2004 editions), China Statistics Press, Beijing, 1997-2004.

National Bureau of Statistics: China statistical yearbook 2006, China Statistics Press, Beijing, 2006.

Nissan Automobile Corporation: Handbook of exhaust and fuel efficiency 2005, Atsugi, Japan [in Japanese], 2005.

Oak Ridge National Laboratory (ORNL): LandScan Global population 1998 Database, Oak Ridge National Laboratory, Oak Ridge, Tenn., 1999.

Palmer, P. I., Jacob, D. J., Jones, D. B. A., Heald, C. L., Yantosca, R. M., Logan, J. A., Sachse, G. W., and Streets, D. G.: Inverting for emissions of carbon monoxide from Asia using aircraft observations over the western Pacific, J. Geophys. Res., 108, 8828, doi:10.1029/2003JD003397, 2003.

Parashar, D. C., Gadi, R., Mandal, T. K., and Mitra, A. P.: Carbonaceous aerosol emissions from India, Atmos. Environ., 39, 7861-7871, 2005.

Reddy, M. S. and Venkataraman, C.: Inventory of aerosol and sulphur dioxide emissions from India: Part I - Fossil fuel combustion, Atmos. Environ., 36, 677-697, 2002a.

Reddy, M. S. and Venkataraman, C.: Inventory of aerosol and sulphur dioxide emissions from India. Part II - Biomass combustion, Atmos. Environ., 36, 699-712, 2002b.

Richter, A., Burrows, P., Nues, H., Granier, C., and Niemeijer, U.: Increase in tropospheric nitrogen dioxide over China observed from space, Nature, 437, 129-130, 2005.

State Administration for Coal Safety: China Coal Industry Yearbook 2002, Coal Industry Publishing House, 2003.

SEPA (State Environmental Protection Administration): Report on the state of the environment in China, State Environmental Protection Administration of China, Beijing, 2003.

Streets, D. G. and Waldhoff, S. T.: Biofuel use in Asia and acidifying emissions, Energy, 23, 1029-1042, 1998.

Streets, D. G. and Waldhoff, S. T.: Present and future emissions of air pollutants in China: $\mathrm{SO}_{2}, \mathrm{NO}_{\mathrm{x}}$ and $\mathrm{CO}$, Atmos. Environ., 34, 363-374, 2000.

Streets, D. G., Tsai, N. Y., Akimoto, H., and Oka, K.: Sulfur dioxide emissions in Asia in the period 1985-1997, Atmos. Environ., 34, 4413-4424, 2000.

Streets, D. G., Tsai, N. Y., Akimoto, H., and Oka, K.: Trends in emissions of acidifying species in Asia, 1985-1997, Water Air Soil Poll., 130, 187-192, 2001a.

Streets, D. G., Gupta, S., Waldhoff, S. T., Wang, M. Q., Bond, T. C., and Bo, Y.: Black carbon emissions in China, Atmos. Environ., 35, 4281-4296, $2001 b$.

Streets, D. G., Bond, T. C., Carmichael, G. R., Fernandes, S. D., Fu, Q., He, D., Klimont, Z., Nelson, S. M., Tsai, N. Y., Wang, M.
Q., Woo, J.-H., and Yarber, K. F.: An inventory of gaseous and primary aerosol emissions in Asia in the year 2000, J. Geophys. Res., 108, 8809, doi:10.1029/2002JD003093, 2003.

Streets, D. G., Bond, T. C., Lee, T., and Jang, C.: On the future of carbonaceous aerosol emissions, J. Geophys. Res., 109, D24212, doi:10.1029/2004JD004902, 2004.

Streets, D. G., Zhang, Q., Wang, L., He, K., Hao, J., Wu, Y., Tang, Y., and Carmichael, G. R.: Revisiting China's CO emissions after the Transport and Chemical Evolution over the Pacific (TRACE-P) mission: synthesis of inventories, atmospheric modeling, and observations, J. Geophys. Res., 111, D14306, doi:10.1029/2006JD007118, 2006.

UN (United Nations): Statistical yearbook (twenty-seventh to fortyeighth issues), United Nations, New York, NY, 1983-2004.

Uno, I., He, Y., Ohara, T., Yamaji, K., Kurokawa, J., Katayama, M., Wang, Z., Noguchi, K., Hayashida, S., Richter, A., and Burrows, J. P.: Systematic analysis of interannual and seasonal variations of model-simulated tropospheric $\mathrm{NO}_{2}$ in Asia and comparison with GOME-satellite data, Atmos. Chem. Phys., 7, 1671-1681, 2007 , http://www.atmos-chem-phys.net/7/1671/2007/.

US EPA (United States Environmental Protection Agency): Compilation of air pollutant emission factors (AP-42) Volume 1: point and area sources, U.S. Environmental Protection Agency, Research Triangle Park, NC, 1999.

USGS (United States Geological Survey): USGS mineral yearbook volume III. - area reports: international, available at: http: //minerals.usgs.gov/minerals/pubs/myb.html, 2006.

Van Aardenne, J. A., Carmichael, G. R., Levy, H., Streets, D., and Hordijk, L.: Anthropogenic $\mathrm{NO}_{\mathrm{x}}$ emissions in Asia in the period 1990-2020, Atmos. Environ., 33, 633-646, 1999.

Van Aardenne, J. A., Dentener, F. J., Olivier, J. G. J., Klein Goldewijk, C. G. M., and Lelieveld, J.: A $1^{\circ} \times 1^{\circ}$ resolution data set of historical anthropogenic trace gas emissions for the period 18901990, Global Biogeochem. Cy., 15, 909-928, 2001.

Veldt, C. and Berdowski, J. J. M.: GEIA-note on the combustion of biomass fuels (emission factors for $\mathrm{CO}, \mathrm{CH}_{4}$ and NMVOC), TNO-report, TNO-MW-R 94/218, 1995.

Wang, J., Yang, J., Ma, Z., and Benkovic, S.: $\mathrm{SO}_{2}$ Emission Trading Program-US Experience and China's Perspective, China Environmental Science Publishing Company, Beijing, 2000.

Wang, J., Yang, J., Benkovic, S., Schreifels, J., and Ma, Z.: $\mathrm{SO}_{2}$ Emission Trading Program-A feasibility study for China, China Environmental Science Publishing Company, Beijing, 2002.

World Bank: World Development Indicators 2006, The world bank, Washington, D.C., 2006.

Xue, Z., Yang, Z., Zhao, X., Chai, F., and Wang, W.: Distribution of $\mathrm{SO}_{2}$ and $\mathrm{NO}_{\mathrm{x}}$ emissions in China, 1995, Proceedings of the 6th International Conference on Atmospheric Sciences and Applications to Air Quality, Beijing, China, 3-5 November, 1998.

Yamaji, K., Ohara, T., and Akimoto, H.: A country-specific, highresolution emission inventory for methane from livestock in Asia in 2000, Atmos. Environ., 37, 4393-4406, 2003.

Yamaji, K., Ohara, T., and Akimoto, H.: Regional-specific emission inventory for $\mathrm{NH}_{3}, \mathrm{~N}_{2} \mathrm{O}$, and $\mathrm{CH}_{4}$ via animal farming in South, Southeast, and East Asia, Atmos. Environ., 38, 71117121, 2004.

Yan, X., Cai, Z. C., Ohara, T., and Akimoto, H.: Methane emission from rice fields in mainland China: amount and sea- 
sonal and spatial distribution, J. Geophys. Res., 108, 4505, doi:10.1029/2002JD003182, 2003a.

Yan, X., Akimoto, H., and Ohara, T.: Estimation of nitrous oxide, nitric oxide, and ammonia emissions from croplands in East, Southeast, and South Asia, Global Change Biol., 9, 1080-1096, 2003 b.

Yan, X., Ohara, T., and Akimoto, H.: Development of regionspecific emission factors and estimation of methane emission from rice field in East, Southeast and south Asian countries, Global Change Biol., 9, 237-254, 2003c.

Yan, X., Ohara, T., and Akimoto, H.: Bottom-up estimate of biomass burning in mainland China, Atmos. Environ., 40, 52625273, 2006.

Yumimoto, K. and Uno, I.: Adjoint inverse modeling of CO emissions over Eastern Asia using four-dimensional variational data assimilation, Atmos. Environ., 40, 6836-6845, 2006.
Zhang, J., Smith, K. R., Uma, R., Ma, Y., Ye, S., Kishore, V. V. N., Lata, K., Khalil, M. A. K., Rasmussen, R. A., and Thorneloe, S. T.: Carbon monoxide from cookstoves in developing countries: 1. Emission factors, Chemosphere, 1, 353-366, 1999.

Zhang, J., Smith, K. R., Ma, Y., Ye, S., Jiang, F., Qi, W., Liu, P., Khalil, M. A. K., Rasmussen, R. A., and Thorneloe, S. A.: Greenhouse gases and other airborne pollutants from household stoves in China: a database for emission factors, Atmos. Environ., 34, 4537-4549, 2000.

Zhou, D., Dai, Y., Yi, C., Guo, Y., and Zhu, Y.: China's sustainable energy scenarios in 2020, China Environmental Science Press, Beijing [in Chinese], 2003. 